\title{
The evolution of the productivity dispersion of firms - A reevaluation of its determinants in the case of Japan
}

\author{
Keiko ITO* \\ Senshu University \\ Sébastien LECHEVALIER \\ EHESS and Maison Franco-Japonaise
}

May 2008

\begin{abstract}
There is a growing body of literature analyzing empirically the evolution of productivity dispersion at the firm level and its determinants. This paper contributes to this literature by investigating the case of Japanese firms during the so-called "Lost Decade" (19922005), which is still under-analyzed. We use a firm-level panel dataset taken from a large-scale administrative survey, the Basic Survey of Japanese Business Structure and Activities (BSBSA) for the years 1994-2003.

Our results can be summarized as follows. First, we confirm that there was an overall increase in both labor productivity and total factor productivity dispersion, especially in the manufacturing sector from 1998 onward. Second, in the case of Japanese firms during the Lost Decade, and contrary to what has been found for some other countries, we find no significant impact of the introduction of information and communication technologies (ICT) on productivity dispersion. On the other hand, we do find evidence of a significant and positive impact of internationalization on productivity dispersion. In addition, the evolution of the competitive environment appears to play a role: we find that the increase in the Hershman-Herfindahl index observed in some sectors, which characterizes a more oligopolistic environment, is associated with an increase in productivity dispersion.
\end{abstract}

JEL Classification: L23, L25, O33, B52.

Key words: heterogeneity of firms, productivity dispersion, Japanese economy.

* Corresponding author: K. Ito, keiko-i@isc.senshu-u.ac.jp 


\section{Introduction}

Heterogeneity in the performance of firms has long been recognized and indeed is a wellestablished fact that has been studied even before the seminal papers of Nelson (1981; 1991). In the past few years, this topic has been the focus of an increasing number of studies. One reason is theoretical: new international trade theories have emphasized the role of firm heterogeneity, especially in order to explain various stylized facts such as the growth of intra-industry trade (Helpman, 2006). More generally, the persistence of productivity differentials across firms raises questions about the validity of the representative firm hypothesis (Aoki and Yoshikawa, 2006). Another reason is more empirical: one of the key starting points of the research agenda on productivity dispersion across firms is the recognition that it may be the basis for observed increases in wage inequality (Davis and Haltiwanger, 1991; Mortensen, 2003). Finally, another important reason is that economists now have at their disposal new datasets allowing them to more precisely assess issues related to firm heterogeneity. The use of longitudinal micro-level datasets (LMDs) to analyze productivity at the firm or plant level has led to a focus on the significant dispersion between productive units of firms operating in the same environment (country or sector) and of similar size (Bartelsman and Doms, 2000). Moreover, the finding that this dispersion is persistent over time - that is, highly productive firms (plants) today are more than likely to be highly productive tomorrow - has led some researchers to investigate why and how between-firm (-plant) productivity dispersion evolve over time.

While the existence of significant and persistent dispersions of productivity is well established, the theoretical and empirical analysis of their evolution over time is still in an early stage of development. The purpose of this paper is to contribute to this literature by empirically examining the role of a set of factors generally recognized as determinants of the evolution of productivity dispersion using a dataset of Japanese firms.

Among the various theoretical explanations of the evolution of productivity dispersion, the impact of innovation is certainly the most popular. For example, Caselli (1999) built a model in which an increasing productivity dispersion is generated by differences in the rate of technology adoption. Other theoretical explanations focus on the impact of internationalization (Melitz, 2003), market competition (Syverson, 2004a; 2004b), or institutional factors (Aoki, 2000). On the empirical side, studies have tended to confirm the technology explanation (e.g., Dunne et al. [2004] for the case of the US and Faggio et al. [2007] for the case of the UK). However, we are still far from a clear understanding of the determinants of the evolution of productivity dispersion. For example, with regard to openness to trade, Del Gatto et al. (2007) 
found a significant negative impact on productivity dispersion, whereas Syverson's (2004b) study suggests that this is not a significant determinant.

Recent studies on Japan, using different datasets and different methodologies, have found an increasing heterogeneity of productivity among Japanese firms during the so-called "Lost Decade” (1992-2005) (Morikawa, 2007; Fukao and Kwon, 2006; Shinada, 2003). However, the analysis of productivity dispersions in Japan still lags behind those in the United States and Europe. Against this background, the aim of this paper is to expand on previous studies on the heterogeneity of Japanese firms. To do so, we use the Basic Survey of Japanese Business Structure and Activities (BSBSA, or Kigyo Katsudo Kihon Chosa) for the years 1994-2003. The BSBSA is a large-scale administrative survey conducted annually by the Ministry of Economy, Trade and Industry (METI). Following the methodology of Faggio et al. (2007), we build different indicators of productivity dispersion to study the evolution of dispersion and test the impact of various determinants, including technical change, internationalization, and competition. Our basic finding is that, in the case of Japan during the Lost Decade, the introduction of information and communication technologies (ICT) does not appear to have had a significant impact on productivity dispersion, while internationalization and the competitive environment did.

The remainder of this paper is organized as follows. In the next section, we review the theoretical and empirical literature regarding the heterogeneity of firms. In Section 3, we assess the increasing heterogeneity of firm performance. In Section 4, we then estimate the determinants of the increasing dispersion, while Section 5 concludes.

\section{Literature review}

\subsection{Theoretical insights on the determinants of the evolution of firm heterogeneity}

\section{Technology and dispersion}

The simplest explanation of productivity dispersion is differences in factor intensity, for example in the capital/labor ratio. However, very few models have investigated this point, an exception being Leonardi (2007). This perspective is not common in the mainstream literature, no doubt because the assumption of differences in capital/labor ratios is in conflict with the view that one should observe a process of convergence of factor intensities among firms. In this context, it appears to be difficult to explain any increasing dispersion. ${ }^{1}$

\footnotetext{
${ }^{1}$ However, in empirical analysis, it is nevertheless important to control for differences in factor intensities.
} 
In fact, among the various models aiming at explaining the evolution of productivity dispersion, those focusing on the role of technical change are by far the most common. For example, in a Neo-Schumpeterian perspective, technical change is the key, or even the only, determinant in the evolution of productivity heterogeneity (Nelson, 1991). The reason is that innovation is the main way for firms to differentiate themselves from their competitors. More specifically, we can find two explanations of the role of innovation in increasing dispersion. The first can be found in the model of Caselli (1999), where an increased dispersion in wages and productivity across establishments is linked to different rates of technology adoption across establishments. In fact, the timing of the introduction of new technology is particularly important in the context of accelerating technical progress. The second explanation relates to the use of technology. To transform new technology into productivity gains, it is essential for firms to reorganize (Nelson, 1991), which is much more complex than just buying new computers, for example. The technical change is accompanied by an organizational change which may be an even more dramatic source of productivity dispersion across firms.

While innovation is one driver of technical change, diffusion is the other, and technical change brought about by diffusion should reduce the dispersion of performance across firms. Therefore, a more complex view of the impact of technology on the dispersion of productivity recognizes the co-existence of centrifugal and centripetal forces, as, for example, Fung (2005) does, who considers $R \& D$ expenses and knowledge spillovers as two complementary sources of technical change.

\section{Internationalization}

Another common theoretical explanation of the evolution of productivity dispersion concentrates on the role of globalization. However, compared with technical change, the impact of globalization on productivity dispersion is more ambiguous. What is more, the effect of globalization is difficult to distinguish from the effect of competition: industries with greater exposure to international trade should be characterized by less productivity dispersion because of the greater competition.

Beyond the competition effect, the impact of globalization on productivity dispersion can be divided into a transitional stage and an equilibrium state (see, e.g., Melitz, 2003, and Helpman, 2006). In the transitional stage, productivity dispersion may increase because of the cumulative impact of two effects. The first is the selection effect, with only the most productive firms serving the international market. The second is the learning effect, with internationalized firms becoming more productive. If these two potential effects reinforce each other, internationalization may 
produce an increasing dispersion of productivity. In this case, the hierarchy among firms in terms of their performance would be reinforced, with less productive firms serving only the domestic market, the most productive firms engaging in foreign direct investment (FDI), and those in between exporting. ${ }^{2}$ To sum up, in this transitional stage, internationalization allows productive firms to become more productive and gain a larger market share. However, in equilibrium, if the natural selection mechanism is functioning well, productivity dispersion should decrease due to the internationalization. Indeed, following the internationalization of a sector, the cut-off productivity level will rise and less productive firms falling below this threshold will be forced to exit.

Another mechanism linking internationalization and productivity dispersion is analyzed by Antras and Helpman (2004). The authors show that the strategic decision of international outsourcing by a given firm will depend on the initial productivity dispersion. The more productivity is dispersed, the larger the fraction of firms will be that will outsource to lower-wage countries, which leads to a higher import penetration ratio at the industry level. Melitz (2003) finds that greater dispersion raises the share of exporting firms in domestic output, while Helpman et al. (2004) find that greater dispersion raises horizontal FDI relative to exports.

\section{The market environment: product substitutability, competition, and business cycles}

While most of the theoretical explanations of the evolution of productivity dispersion deal with the supply side, it is important to mention the attempt by Syverson (2004a; 2004b) to model a demand-side explanation. To put it simply, Syverson analyzes the relationship between product substitutability and productivity dispersion and shows that market conditions characterized by low substitutability should go hand-in-hand with a high productivity dispersion. Low product substitutability prevents customers from shifting from goods produced by relatively less productive firms to goods produced by relatively more productive firms. Thus, anything that increases product substitutability should lower productivity dispersion.

Closely related to this argument, and on a more general level, it seems likely that the competitive environment affects the level of productivity dispersion, that is, the more competitive a given market is, the less should productivity be dispersed, since competition promotes the exit of less productive firms.

Finally, business cycles are another potential "environment-related" determinant of the evolution of the heterogeneity of firms. From a Schumpeterian perspective, the natural selection

\footnotetext{
${ }^{2}$ This hierarchy has been confirmed in several empirical studies. Examples for the case of Japan include Head and Ries (2003) and Kimura and Kiyota (2006).
} 
mechanism in a market economy, which is particularly severe during recessions, leads to the exit of the worst-performing firms and therefore to greater homogeneity (Aghion and Saint-Paul, 1991).

\section{Institutional explanations}

Finally, as emphasized by the theories of comparative capitalisms, the institutional changes that occurred in the 1980s and 1990s have affected the organizational diversity of firms and therefore their performance dispersion (Deeg and Jackson, 2007; Lechevalier, 2007). More precisely, the process of liberalization in the most developed economies did not lead to the disappearance of rules but rather to the coexistence of old and new rules. This institutional layering has led to the differential adoption of old and new business practices according to firmspecific characteristics. Another potential channel through which institutional changes affect productivity dispersion is the fact that firms may not be affected to the same degree: for example, deregulation may differ by sector or some firms may be exempted from certain new rules according to a size criterion. This effect of deregulation, by potentially increasing dispersion, may therefore go in the opposite direction of the effect of competition.

\subsection{Previous empirical studies on the evolution of productivity dispersion in Japan}

The number of empirical studies investigating the determinants of the evolution of productivity dispersion across several sectors is still limited. Most preceding studies confirm that the introduction of new technology has a positive impact on dispersion, that is, they confirm the Caselli model (e.g., Dunne et al., 2004, focusing on the United States and Faggio et al., 2007, using UK data). Regarding the other factors, the results are less clear. For example, Syverson (2004b) finds that internationalization increases dispersion or has no significant impact. This is at odds with the predictions of Melitz's model (2003) and Del Gatto et al.'s (2007) results confirming the model. As for the market environment, Syverson (2004a; 2004b) confirms the predictions of his own model.

To date, the number of studies on the dispersion of productivity among Japanese firms is even more limited. Several papers provide evidence of an increasing heterogeneity of firm performance, but they do not systematically investigate the causes of this trend (Shinada, 2003; Fukao and Kwon, 2006; and Morikawa, 2004 and 2007). For example, using a sample of 604 listed manufacturing and non-manufacturing companies spanning the period 1980-2000, Shinada (2003) found some evidence of increasing intra-industry productivity differences in the 1990s. 
Specifically, he found that, dispersions in productivity emerged between firms in most manufacturing industries from the latter half of the 1990s, while intra-industry disparities were less apparent in the case of non-manufacturing industries.

Regarding the causes of increasing heterogeneity, Fukao and Kwon (2006) were able to confirm that technical progress plays a role in the increasing heterogeneity among firms by examining productivity differences across sectors. Specifically, analyzing inter-firm differences in TFP by measuring the gap in the TFP level between a group of high-TFP firms and a group of low-TFP firms and comparing the characteristics of the two groups of firms, they show that the TFP gap is widening in many industries, including drugs and medicine, electronic data processing machines and electronic equipment, and motor vehicles, where R\&D-intensity is high. However, they did not test directly the relationship between R\&D intensity and the evolution of dispersion at the industry level, nor did they clearly explain the mechanisms at work, suggesting simply that differences in $R \& D$ intensity will lead to differences in performance at the firm level, especially in sectors where R\&D is a crucial determinant of productivity.

As for the impact of internationalization on productivity dispersion, Fukao and Kwon (2006) found that the TFP gap appears to be widening in industries where internationalization as measured by outward direct investment, inward direct investment, and procurements from abroad - is more advanced, a result that is in conflict with the theoretical prediction presented above that at equilibrium, internationalization should result in less dispersion. They also found that high-TFP firms tend to have a higher degree of internationalization and that internationalization has positive effects on a firm's TFP growth. However, the authors do not provide a direct test of the impact of internationalization on productivity dispersion, nor do they attempt to interpret their result, i.e., whether it reflects a malfunctioning of the natural selection mechanism or the type of reverse causality predicted by the model of Antras and Helpman (2004).

With regard to the role of business cycles, does the Schumpeterian mechanism described above hold in severe recessions, like the one that Japan experienced in the second half of the 1990s? Research by Nishimura et al. (2005) suggests that the answer is negative and that it was relatively efficient firms in terms of their TFP that went out of business while relatively inefficient ones survived during the banking crisis of 1996-1997. In other words, the recession de facto led to an increase in the heterogeneity of firms' performance.

Finally, concerning the role of institutional factors, Aoki et al. (2007) suggest that there is growing heterogeneity in corporate governance in Japan, and the reason for this basically is that not all firms are equally exposed to pressure for change and that existing institutions also constrain change along particular trajectories (Aoki et al., 2007). For example, the foreign 
investors concentrate in some firms and this has a strong impact on their corporate governance: firms with a high foreign ownership ratio are more likely to adopt "Anglo-American"-style corporate reforms or modes of restructuring. The result is a clearly growing diversity among Japanese firms in terms of organizational practices. Another reason for the growing heterogeneity is related to the way some regulatory reforms have been implemented in Japan. For example, regulatory reforms concerning firms' board of directors have been dodged by strong opposition between two major actors, METI and Keidanren (Japan Federation of Economic Organizations). The result has been a compromise, which allows firms to choose between a traditional board and an American-type board, leading to diverging practices in terms of corporate governance (Aoki et al., 2007). ${ }^{3}$ Generally speaking, many studies of corporate governance and organization in Japan come to the conclusion that practices among Japanese firms are becoming more heterogeneous. However, this result has still to be linked more rigorously with the increased performance dispersion.

Although the role of the institutional environment in shaping firm heterogeneity represent a promising research area, it is very difficult to examine empirically. That is why in the analysis in Section 4 we will concentrate our attention on the other factors that have been described above, i.e., technical change, internationalization, and competition. ${ }^{4}$ Before turning to the analysis of the determinants of the evolution of dispersion, we first examine the characteristics of this evolution.

\section{The evolution of labor productivity and TFP distribution (1994-2003)}

\subsection{Description of the dataset and measurement of productivity}

We use the firm-level panel data underlying the Basic Survey of Japanese Business Structure and Activities (BSBSA) conducted annually by the METI. ${ }^{5}$ Our data cover the period from 1994 to 2003.

\footnotetext{
${ }^{3}$ Apart from the legal structure, another element that may have contributed to the increasing diversity of corporate governance among Japanese firms is changes in the role of main banks and capital markets. These have lessened constraints on firms with regard to choices in other domains, such as their business strategy and structure, management, and employment patterns. Firms have responded to this changing environment in diverse ways (Aoki, 2000).

${ }^{4}$ As for the impact of business cycles, we do not include this in our analysis because it requires a different methodology to be estimated.

${ }^{5}$ The survey covers all firms with at least 50 employees or 30 million yen of paid-in capital in the Japanese manufacturing, mining, commerce, and several other service sectors. The survey contains detailed information on firmlevel business activities such as the 3-digit industry in which the firm operates, its number of employees (including a breakdown of the number of employees by firm division), sales, purchases, exports, and imports (including a breakdown of the destinations of sales and exports and the origin of purchases and imports), R\&D and patents, the
} 
Although industry information is available at the 3-digit level in the survey, our analysis is based on the JIP micro-data industry classification, which consists of 40 sectors, as shown in Table $1 .{ }^{6}$ However, due to the insufficient number of observations, our analysis below is limited to 34 sectors, excluding the following six industries: agriculture, forestry and fisheries (industry no. 31), mining (32), construction (33), electricity, gas, and heat supply (34), finance (38), and other industries (40). We drop from our dataset all firms for which data on sales, the number of employees, total wage payments, tangible fixed assets, depreciation, or intermediate inputs are non-positive or missing at least for one year. After this data screening, our unbalanced panel dataset consists of approximately 23,000 firms for each year. Out of the 23,000 firms, approximately 12,000 firms are in the manufacturing sector while approximately 11,000 firms are in the non-manufacturing sector. Moreover, out of the 11,000 non-manufacturing firms, approximately 9,000 are in the wholesale or retail trade sectors.

\section{INSERT Table 1}

Utilizing the firm-level panel data, we construct two kinds of productivity measures, labor productivity and TFP. Labor productivity is simply calculated as the real value added per employee as we do not have any information on working hours at the firm level. Real value added is calculated as the real sales amount minus real intermediate input using industry-level price deflators taken from the JIP Database 2006.

As for TFP, we follow Good et al. (1997) and define the TFP level of firm $i$ in year $t$ in a certain industry in comparison with the TFP level of a hypothetical representative firm in base year 0 in that industry by:

$$
\begin{aligned}
& \ln T F P_{i, t}=\left(\ln Q_{i, t}-\overline{\ln Q_{t}}\right)-\sum_{f=1}^{n} \frac{1}{2}\left(S_{f, i, t}+\overline{S_{f, t}}\right)\left(\ln X_{f, i, t}-\overline{\ln X_{f, t}}\right) \\
& \left.\left.+\sum_{s=1}\left(\overline{\ln Q_{s}}-\overline{\ln Q_{s-1}}\right)-\sum_{s=1}^{t} \sum_{f=1}^{n} \frac{1}{2}\left(\overline{S_{f, s}}+\overline{S_{f, s-1}}\right) \overline{\left(\ln X_{f, s}\right.}-\overline{\ln X_{f, s-1}}\right)\right]
\end{aligned}
$$

\footnotetext{
number of domestic and overseas subsidiaries, and various other financial data such as costs, profits, investment, and assets.

${ }^{6}$ Deflators for output, input, and capital prices, etc. are not available at the 3-digit industry level. In order to utilize the JIP Database 2006 price deflators, we reclassified industries according to the 40 JIP micro-data industry classifications. The JIP Database 2006 was compiled as part of the RIETI research project "Study on Industry-Level and Firm-Level Productivity in Japan.” It contains sector-level information on 108 sectors from 1970-2002 that can be used for industry-level TFP analysis. The database is available from the RIETI website:

$<$ http://www.rieti.go.jp/en/database/d05.html>.
} 
where $Q_{i, t}, \mathrm{~S}_{f, i, t}$, and $\mathrm{X}_{f, i, t}$ denote the gross output (real sales) of firm $i$ in year $t$, the cost share of factor $f$ for firm $i$ in year $t$, and firm $i$ 's input of factor $f$ in year $t$, respectively. The variables with an upper bar denote the industry average of that variable. We assume constant returns to scale. As factor inputs, we take account of capital, labor, and real intermediate inputs. ${ }^{7}$

\subsection{Assessing increasing productivity dispersion at the aggregate level}

To assess productivity dispersion at the aggregate level, we first consider the manufacturing and non-manufacturing sectors, excluding the six industries mentioned above. The remainder of the analysis is made by separating manufacturing industries and non-manufacturing industries. We proceed in a way similar to that adopted by Faggio et al. (2007), that is, we compute values at the $90^{\text {th }}, 50^{\text {th }}$ (median) and $10^{\text {th }}$ percentiles and normalize these to unity in 1994 . The series therefore represent cumulative changes relative to the initial year, 1994.

\section{INSERT Figures 1(a) and 1(b)}

Looking first at the labor productivity figures (Figures $1[\mathrm{a}]$ and $1[\mathrm{~b}]$ ), we find that in both manufacturing and non-manufacturing the dispersion of labor productivity has increased. This trend is a little more pronounced in the case of the manufacturing sector than in the nonmanufacturing sector, as the differential between the $90^{\text {th }}$ percentile and the $10^{\text {th }}$ percentile has increased by 37\% and 34\%, respectively. This result is the opposite of that obtained by Faggio et al. (2007) for the case of the UK. Looking at the evolution of productivity dispersion in more detail, we find that there are slight differences in the two sectors. In terms of timing, the dispersion started to increase in 1996 in the non-manufacturing sector (that is, during a period when the Japanese economy was still expanding) and two years later in the case of manufacturing industries, in 1998, which is the beginning of the most severe downturn of the Japanese economy during the Lost Decade. Another striking difference is that in the case of the non-manufacturing sector, the $10^{\text {th }}, 50^{\text {th }}$, and $90^{\text {th }}$ percentiles follow quite contrasting trajectories. This means that the increasing dispersion is due almost as much to the very poor performance of the $10^{\text {th }}$ percentile as to the relatively good performance of the $90^{\text {th }}$ percentile. On the other hand, in the case of the manufacturing sector, the performance of the $10^{\text {th }}$ percentile is very similar to the performance of the median, and the increasing dispersion is essentially due to the good performance of the $90^{\text {th }}$ percentile.

\footnotetext{
${ }^{7}$ For details of the definition and source of each variable, see the Appendix.
} 
INSERT Figures 2(a) and (b)

Next, looking at TFP, the pattern in the evolution of productivity in manufacturing and non-manufacturing differs quite substantially (Figures 2[a] and 2[b]). In the case of the manufacturing sector, we again find an increasing dispersion, which, however, is much less pronounced than that for labor productivity: the dispersion between the $10^{\text {th }}$ percentile and the $90^{\text {th }}$ percentile has increased of $12 \%$ between 1994 and 2003. As for the timing and the decomposition of the evolution, it is very similar to what we found in the case of labor productivity: the dispersion starts increasing in 1998 and is the result of the relatively good performance of the $90^{\text {th }}$ percentile. In the case of the non-manufacturing sector, we do not find any significant increase in dispersion. The most striking feature is the cyclical movement for all three percentiles with two peaks, in 1996 and 2000. This result should be interpreted very carefully as it may spring from data problems, related to price deflators or the adjustment of working hours. Although we adjusted working hours using the sectoral data from the JIP Database 2006 in the case of the TFP calculation, we could not adjust working hours at the firmlevel due to the unavailability of data. Moreover, the majority of firms in the non-manufacturing sector fall into two sectors, wholesale trade and retail trade. Our deflators are not disaggregated by the detailed product level, despite the fact that each firm sells different products in these industries. Such deflator problems may create serious measurement errors. The improvement of deflators is an issue left for future research.

To summarize the results we obtained so far, the increase in dispersion is much more pronounced in the case of labor productivity than in the case of TFP. It is also more pronounced in the case of the manufacturing than the non-manufacturing sector, which is in contrast with results obtained by Faggio et al. (2007) for the case of the UK. Due to this difference between the manufacturing and the non-manufacturing sector and to the potential measurement problems, we will focus on the former.

\subsection{Decomposing productivity dispersion}

In the next step of our analysis, we decompose labor productivity dispersion in the manufacturing sector overall into between-industry and within-industry components. Some previous studies, such as Morikawa (2007) for Japan and Faggio et al. (2007) for the UK, suggest that the within-industry component dominates the between-industry component. Following the decomposition methodology used by Morikawa (2007), we examine the trend of these two 
components for the period from 1994 to 2003. The overall variance of firm-level labor productivity in the manufacturing sector is decomposed into a within-industry component and a between-industry component using the following formula:

$$
\operatorname{Var} p_{I t}=V\left(S_{I t}, \sigma_{I t}^{2}, p_{I t}\right)=\sum_{I} S_{I t} * \sigma_{I t}^{2}+\left\{\Sigma_{I} S_{I t} * P_{I t}{ }^{2}-\left(\Sigma_{I} S_{I t} * P_{I t}\right)^{2}\right\}
$$

where $s_{I t}$ is the share of the number of firms in industry $I$ in the total number of firms in year $t, \sigma_{I t}^{2}$ is the variance of the log of labor productivity (value added per employee) for industry $I$ in year $t$, $p_{I t}$ is the log of labor productivity for each firm in industry $I$ and year $t$, and $P_{I t}$ is the average $p_{I t}$ over industry $I$ and year $t$.

\section{INSERT Figures 3(a) and (b)}

The first term of the right-hand side of the above formula is the within-industry component and the terms in brackets indicate the between-industry component. Figure 3(a) shows the relative magnitudes of the within and the between components calculated based on the real value of labor productivity. On the other hand, Figure 3(b) shows the relative magnitude calculated based on the nominal value of labor productivity. Figure 3(a) suggests that the between-industry component has been becoming more important over time, although the majority of the productivity variance is still attributable to the within-industry component in 2003. As the decomposition analysis using the real value depends on the base year for the price deflators, we also need to check the decomposition using the nominal value. Figure 3(b) shows that nearly 90 percent of the overall variance is attributable to the within-industry components for all years and the relative magnitudes are very stable when we conduct a decomposition analysis using the nominal value. These figures confirm that there is a significant variation in firm-level productivity within an industry. In the following sub-section, we analyze the within-industry productivity dispersion in detail.

\subsection{Differences across industries}

The increasing dispersion of productivity, which we found at the aggregate level, varies across manufacturing industries. In Figures 4(a) to (d), we rank industries in decreasing order of the evolution (between two sub-periods, 1994-1998 and 1999-2003) of the average distance of labor productivity (Figures $4[\mathrm{a}]$ and $4[\mathrm{~b}]$ ) and of TFP (Figures $4[\mathrm{c}]$ and $4[\mathrm{~d}]$ ) between the first 
quartile and the last quartile. In the case of labor productivity, the number of industries which experienced an increasing dispersion and the number of industries which experienced a decreasing dispersion is almost the same. But the extent of change is much greater in the case of industries with an increasing dispersion. As for TFP, only two industries experienced a decreasing dispersion. However, the range of values for TFP is much smaller than in the case of labor productivity. Moreover, it is important to note that a simple Spearman Test of correlation shows that the ranking in terms of the change in dispersion between the two sub-periods is different in the case of labor productivity and TFP. A possible interpretation of this result is that the changes in labor productivity dispersion may not be only related to, or directly related to, technological characteristics, as we might expect in the case of TFP. That this intuitive interpretation seems correct is shown in Section 4, where we estimate various models.

INSERT Figures 4(a) and 4(b)

Although the rankings for labor productivity and TFP are somewhat different, we can find a number of similarities between the results for the two measures. Basically, it appears that the computer equipment and accessories industry (industry no. 24) shows a conspicuous increase in productivity dispersion, regardless of the measure. ${ }^{8}$ Industries such as rubber products (12), ceramic, stone and clay products (13), miscellaneous electrical machinery equipment (26), motor vehicles and parts (27), and other transport equipment (28) also show a relatively large increase in dispersion in terms of both labor productivity and TFP. However, we can also see some discrepancies between the change in dispersion of labor productivity and TFP. First, industries such as petroleum and coal products (10), textile products (2), and iron and steel (10) have experienced a significant increase in their productivity dispersion when one looks at the labor productivity, whereas this is not the case for TFP. Second, in the case of industries such as household electric appliances (22), communication equipment (23), and electronic parts and devices (25), we find a relatively large increase in TFP dispersion, but a decrease in labor productivity dispersion. As it seems likely that the TFP measure is subject to more serious measurement error, we will rely on the labor productivity measure in the remainder of the analysis in this paper. Improving measurement accuracy to allow an analysis using the TFP measure represents an important task to be tackled in future research.

\footnotetext{
${ }^{8}$ Because of problems of scale, the computer equipment and accessories industry is not shown in Figures 4(c) and (d): the extent of increase in the dispersion is six times greater than that for the industry with the second-highest increase (ceramic, stone, and clay products).
} 


\section{Determinants of productivity dispersion}

Having confirmed that productivity dispersion within industries is indeed increasing, the next task of our analysis is to examine the reasons for this trend. In this section, we therefore conduct a regression analysis to investigate the relationship between productivity dispersion and possible sources of the dispersion.

\subsection{Specification and estimation procedure}

\section{Dependent and explanatory variables}

As mentioned in Section 2, productivity dispersion can potentially be explained by both supply-side production and demand-side market factors. Supply-side factors, as highlighted above, include technology shocks, management skill or corporate governance, R\&D activities, or investment patterns. On the other hand, the importance of demand-side market conditions are raised and empirically confirmed by the seminal paper by Syverson (2004b). Moreover, internationalization and institutional factors are also considered to have a relationship with persistent dispersion of productivity.

Following Syverson (2004b) and Del Gatto et al. (2007), we test the link between withinindustry productivity dispersion and various industry characteristics by estimating the following equation:

$$
y_{I t}=\beta+X_{I t} B_{I t}+\sum_{I} \gamma_{I} S_{I}+\sum_{t} \mu_{t} T_{t}+\varepsilon_{I t} \quad \text { with } \mathrm{I}=1, \ldots, 30 ; \mathrm{t}=1994, \ldots, 2003
$$

where the within-industry productivity dispersion moment $y_{I t}$ (a dispersion or central measure) for industry $I$ in year $t$ is a function of a constant, a vector $X_{I t}$ of industry characteristics on the moments, industry fixed effects, year fixed effects, and a disturbance term.

The productivity dispersion moments in this estimation are computed for 30 manufacturing industries using the firm-level data underlying the BSBSA for the period from 1994 to 2003. We compute industry productivity moments with two different measures. One is a labor productivity measure, the logarithm of the value added per employee $(\ln V A P)$. In addition to the labor productivity measure, we estimate the model with a TFP measure $(\ln T F P)$. We 
measure industry dispersion as the interquartile productivity difference $(I Q \ln V A P, I Q \ln T F P)$ as well as the difference between the $90^{\text {th }}$ and $10^{\text {th }}$ productivity percentiles (IDInVAP, ID $\ln T F P$ ), in order to see if the results are sensitive to the choice of productivity dispersion measures. For the labor productivity measure, the dispersion measure is standardized by dividing by the median to prevent pure scale differences between industries. Following previous studies such as Syverson (2004b), Del Gatto et al. (2007), and Faggio et al. (2007), we use the ordinal moments rather than variance in order to minimize the influence of outliers.

As explanatory variables, we mainly consider the following three factors suggested by previous studies: technical progress, output market conditions, and openness to trade. The definitions of the explanatory variables are summarized in Table 2. As a proxy for technical progress, we prepare two variables: R\&D intensity and the ICT capital stock ratio (IT ratio). The industry $R \& D$ intensity is calculated as the total $R \& D$ expenditure of firms in the industry divided by the total sales of firms in the industry, using the firm-level data of the BSBSA. The industry ICT capital stock ratio is calculated as the real ICT capital stock divided by the sum of real ICT capital stock and real non-ICT capital stock, taken from the JIP Database 2006. ${ }^{9}$ If different rates of technology adoption generate increasing dispersion, as Caselli (1999) suggests, we expect that productivity dispersion is more pervasive in industries where new technology is more important. However, the impact of technical change on dispersion may be canceled out if technology diffusion is also strong in such industries.

\section{INSERT Table 2}

As factors which represent demand-side output market conditions, we consider product substitutability and an index of market competition. As a product substitutability factor, we use the industry advertising intensity ( $A D V$ intensity), which is constructed as the ratio of industryaggregated advertising expenditure to industry-total sales. As discussed by Syverson (2004b), there are two views on the nature of the relationship between advertising intensity and output substitutability. One view is that advertising (particularly branding) creates artificial product differentiation and, as a result, industries with a higher advertising intensity should exhibit more

\footnotetext{
${ }^{9}$ The ICT capital stock data in the JIP Database 2006 include the following types of assets: Photocopiers and related equipment (JIP asset classification no. 14), office, computing, and accounting machinery (15), TV sets, radios, and audio visual equipment from household electric appliances (excluding VTRs and applied electronic equipment) (17), computers and peripheral equipment (18), wired and wireless communication equipment from communications equipment for business purposes (19), VTRs and applied electronic equipment (20), electric measuring instruments from electricity transmission and distribution apparatus (21), camera and laboratory instruments from other equipment (31), and custom software (38). The JIP Database 2006 can be downloaded from the RIETI website: $<$ www.rieti.go.jp/jp/database/d05.html>.
} 
product differentiation. The opposing view is that advertising provides more information to consumers about superior products, which suggests that advertising, by increasing substitutability across producers, allows more productive firms to take market share away from less efficient competitors. Therefore, according to the first view, an increase in substitutability should be associated with a larger dispersion and lower productivity, while according to the second view, the opposite should be the case. In other words, the effect of higher advertising intensity on substitutability is theoretically ambiguous. As another proxy for the degree of output market competition, we introduce a Hershman-Herfindahl index $(H H I)$. The $H H I$ is calculated as the sum of the square of each firm's sales share for each industry, using the firm-level data of the BSBSA. Output markets are considered to be the more oligopolistic the closer the $H H I$ is to one. As it is more likely for inefficient firms to survive in less competitive markets, we expect that productivity dispersion will be larger in industries with a higher $H H I$.

Another possible explanation of persistent productivity dispersion is the role of internationalization or openness to trade. We use both import penetration (IMPPEN) and export intensity (EXPINT) as proxies for international trade exposure. We calculate import penetration as the ratio of industry product imports to domestic demand (domestic output plus imports minus exports) in the industry, while export intensity is the share of exports in total domestic output of the industry. Larger values of either variable represent greater trade exposure. According to the theories developed by Melitz (2003) and others, greater trade exposure is likely to decrease productivity dispersion at the equilibrium.

Finally, we control for differences in capital intensity in the case of estimations using labor productivity as the dependent variable. The industry capital-labor ratio (KL ratio) is calculated as the total real capital stock divided by the total number of employees in the industry, using the firm-level data of the BSBSA.

Using these variables, we regress industry productivity moments on the various industry characteristics. In addition to testing the within-industry productivity dispersion, we also estimate the equation using median industry productivity as the dependent variable to test the effects of these industry characteristics on the central tendency of productivity distribution.

\subsection{Estimation results}

The estimation results are summarized in Tables 3 and 4 . Table 3 shows the results with the full sample, while Table 4 shows the results using a sample that excludes the computer equipment and accessories industry (industry no. 24). As the increase in productivity dispersion is 
conspicuously large for this industry compared to all other industries, we check whether or not the estimation results are robust to the exclusion of this industry. As for productivity measures, although our estimation results for the central tendency regressions were to some extent consistent regardless of whether labor productivity or TFP was used, most of the estimated coefficients were not statistically significant in the case of the dispersion regressions based on the TFP measure. As the unstable results using TFP dispersion are likely to be partly due to measurement errors, in the discussion below we mainly concentrate on the estimation results using the labor productivity measure. The estimation results based on the TFP measure are presented in Appendix Tables 3 and 4.

The results shown in Table 3 are mostly consistent with those in Table 4 except for the estimated coefficient for the import penetration ratio (IMPPEN). First, the estimated coefficient for $H H I$ is significantly positive in all cases in the productivity dispersion regressions, suggesting that more oligopolistic industries tend to have larger productivity dispersion. Looking at the central tendency regressions, a negative coefficient is estimated for HHI. Therefore, in less competitive and more oligopolistic industries, median productivity tends to be low and productivity dispersion tends to be large. For IT ratio, the estimated coefficient is negative and significant in the productivity dispersion regressions while it is positive and significant in the central tendency regressions. Contrary to Faggio et al.'s (2007) finding of a positive relationship between ICT investment and productivity dispersion, our result, showing a negative relationship, implies that industries with a higher ratio of ICT investment have less dispersion of productivity. This result and its implications are discussed in greater detail in Section 4.4. However, the median productivity level tends to be higher in industries with a higher ICT ratio.

Another rather surprising result is that industries with a higher export intensity (EXPINT) tend to have a larger dispersion of productivity and a lower median productivity level. As described earlier, several theories predict that greater exposure to international trade is associated with less productivity dispersion within an industry (e.g., Melitz, 2003). More productive firms can enter foreign markets and enjoy the benefits of exposure to foreign markets, which should drive the least efficient domestic firms out of business, thereby decreasing productivity dispersion at equilibrium. The empirical study by Del Gatto et al. (2007), using Italian manufacturing data, confirms that more open industries are characterized by a smaller dispersion of real marginal costs (the inverse of TFP) across firms. Our result is at odds with the theoretical prediction and the empirical results by Del Gatto et al. (2007). We discuss this result later. As for the import penetration ratio (IMPPEN), the estimation results with the full sample show a strong positive relationship between trade exposure and productivity dispersion, which is also contrary to the 
theoretical prediction, though Syverson (2004b) also finds a positive relationship between import penetration and productivity dispersion. Moreover, the results of the central tendency regressions show that the median productivity tends to be higher in industries with a higher import penetration ratio. However, this strong positive relationship between import penetration and productivity dispersion disappears when we estimate the model excluding the computer equipment industry.

\subsection{Robustness checks}

The estimation results show a strong positive correlation between export intensity and productivity dispersion, and also show that the median productivity tends to be lower in industries with a higher export intensity. As described above, this result is contrary to the prediction of standard theories and may be related to the malfunctioning of the natural selection mechanism. Therefore, we estimate a specification that includes the survival rate (SURVRT) in order to control for the effectiveness of the natural selection mechanism. The survival rate is calculated as the fraction of firms in year $t$ that still operate in the same industry in year $t+1 .^{10}$

The results including SURVRT are shown in Tables 5 and $6 .{ }^{11}$ The estimated coefficients are mostly consistent with the results in Tables 3 and 4 and are robust. Although the coefficients for EXPINT become insignificant in specification (4), productivity dispersion is still positively, and median productivity still negatively, associated with export intensity even when controlling for the survival rate. As for the estimated coefficients for SURVRT, positive and significant coefficients are estimated in all cases except one in the productivity dispersion regressions, while negative but insignificant coefficients are estimated in the central tendency regressions. These estimated coefficients suggest that productivity dispersion is larger in industries where firms are more likely to survive until the next period. ${ }^{12}$

\subsection{Further discussion and interpretation of the results}

\footnotetext{
${ }^{10}$ As the BSBSA covers firms with 50 employees or more, it is assumed that a firm exited if the number of employees decreased to less than 50. In order to avoid this threshold effect, we construct an alternative measure of the survival rate, which is defined as the fraction of firms with 70 employees or more in year $t$ that still operate in the same industry in year $t+1$. As we obtained similar results, we do not show the results with this alternative measure of the survival rate. ${ }^{11}$ The results including SURVRT based on the TFP measure are shown in Appendix Tables 5 and 6.

12 The equations were also estimated in first differences and included year dummies for further robustness checks. The results are mostly consistent with those shown in the tables in this paper, although the estimated coefficients are less significant. The results of the first-difference estimation can be obtained from the authors upon request.
} 
Among the results analyzed above the most surprising concerns the absence of any effect of the IT ratio on the dispersion of firms, which is at odds with previous analyses, notably Faggio et al. (2007). The literature on the use of ICT and performance at the firm level in Japan may provide explanations for this result. First of all, we should not discount the possibility that this result may come from an inadequate proxy for the use of ICT. Motohashi (2008) has shown that productivity differences among firms in relation to ICT do not come from the overall intensity of ICT use but the way in which ICT is used in a firm (e.g., the degree of informational system use or the degree of back-office-type mission critical system use). If this is indeed the case, the variable IT ratio is not appropriate for capturing the differentiation resulting from IT use. Second, a comparison between Japanese and US firms shows that the productivity effects of network use in the latter are twice as large as those in their Japanese counterparts. Therefore, even if the introduction of ICT has a positive impact on the productivity of Japanese firms, it is apparently less crucial than in the case of American firms (Motohashi, 2008). This result is very similar to the one obtained by Haltiwanger et al. (2003) in their comparison between German and American firms regarding investment in ICT and related business practices and outcomes (such as productivity, employment, the skill mix of the workforce and wages). More precisely, the authors show that the introduction of ICT leads to a higher increase in labor productivity on average and a higher dispersion among US firms than German firms. They then try to explain this fact by comparing the extent of market experimentation in the United States relative to Germany, especially in the cases of young and new businesses. The major result is that US firms engage in experimentation regarding business practices in a variety of ways (such as with regard to the skill mix of workers or internet access for workers) not matched by their German counterparts. Although, to our knowledge, there is no systematic comparison between American and Japanese firms from this point of view, it seems quite reasonable to assume that there are similar behavioral differences between American and Japanese firms. Both the German and the Japanese institutional environment are less favorable to experimentation by firms. The general idea behind this discussion is that the introduction of new technology cannot be isolated as the main determinant of the evolution of productivity dispersion. The organizational changes associated with the use of new technology are at least as important and should be closely analyzed. ${ }^{13}$

As for the positive impact of internationalization on productivity dispersion, our results are also at odds with what models such as those by Melitz (2003) or Helpman (2006) would lead us to expect. There are a number of possible explanations of the result regarding export

\footnotetext{
${ }^{13}$ Another explanation may be that the introduction of ICT at Japanese firms over time was more uniform than in other countries. This point, however, has to be confirmed by further empirical inquiry.
} 
penetration. The first is a possible malfunctioning of the natural selection mechanism, so that the least efficient firms are not forced to exit, or it takes considerable time for them to exit. Second, during this longer process towards equilibrium, productivity dispersion may possibly increase because of the cumulative effects of the two mechanisms - the selection effect and the learning effect - referred to above. The third possible explanation is that in industries with a higher export ratio, a small number of internationalized firms are so efficient that they enable the least efficient firms to continue operating, possibly by offering generous pricing to their less efficient suppliers. Due to the inadequate disaggregation of our industry classification, some firms may be intermediate goods suppliers to other firms in the same industry. As for the positive relationship between productivity dispersion and import penetration, this may be explained by reverse causation, as suggested by Antras and Helpman (2004). In their theoretical model, the strategic decision of offshore outsourcing by a given firm will depend on the initial productivity dispersion. The more productivity is dispersed, the more firms will outsource, resulting in a higher import penetration ratio. Moreover, the industry median productivity rises possibly because more firms can enjoy a cost advantage by outsourcing to lower-wage countries.

\section{Conclusion}

In this study, we investigated the evolution and the nature of productivity dispersion among Japanese firms since the mid-1990s. Confirming the results of previous studies, we found an increasing productivity dispersion, especially from 1998 in the manufacturing sector. Then, focusing on the manufacturing sector, we tried to go one step further and empirically examine the determinants of this increasing dispersion.

Contrary to previous empirical studies focusing on other countries, using our database on Japanese firms we do not find any significant impact of the diffusion of ICT on productivity dispersion. On the other hand, the increasing openness to trade (as measured by the export ratio and import penetration) and the trend toward a more oligopolistic market structure in some industries have played a key role in the increasing dispersion.

Most of the differences between our results and the results of previous studies have still to be explained. One problem concerns the data, especially the calculation of TFP. Solving this problem to provide an accurate alternative measure of productivity could go a long way in helping to understand the evolution of productivity dispersion. Beyond resolving these data problems, it would be useful to understand which institutional or organizational specificities of 
the Japanese economy or which more general mechanisms, not raised in previous analyses, may explain our results. What our empirical study shows is that we cannot account for the increasing dispersion of productivity in Japanese firms by considering only the introduction of new technology. Rather, it is necessary to also consider changes associated with the introduction of technology in areas such as human resource management and the organization of firms. Therefore, an empirical perspective that links the evolution of productivity dispersion to the evolution of organizational heterogeneity appears particularly promising, as it would further our understanding of the chain of causality. These are directions for future research.

\section{References}

AGHION, Philippe and SAINT-PAUL, Gilles (1991), "On the virtue of bad times: An analysis of the interaction between fluctuations and productivity growth," CEPR Working Paper 578, Centre for Economic Policy Research.

ANTRAS, Pol and HELPMAN, Elhanan (2004), “Global sourcing," Journal of Political Economy 112(3): 552-580.

AOKI, Masahiko (2000), Information, Corporate Governance, and Institutional Diversity: Competitiveness in Japan, the USA, and the Transitional Economies, Oxford: Oxford University Press.

AOKI, Masahiko, JACKSON, Gregory and MIYAJIMA, Hideaki (2007), Corporate Governance in Japan: Institutional Change and Organizational Diversity, Oxford: Oxford University Press.

AOKI, Masanao and YOSHIKAWA, Hiroshi (2006), Reconstructing Macroeconomics: A Perspective from Statistical Physics and Combinatorial Stochastic Processes, Cambridge: Cambridge University Press.

BARTELSMAN, Eric J. and DOMS, Mark (2000), "Understanding productivity: Lessons from longitudinal micro-data,” Journal of Economic Literature 38(3): 569-594.

CASELLI, Francesco (1999), “Technological Revolutions,” American Economic Review 89(1): 78-102.

DAVIS, Steve J. and HALTIWANGER, John (1991), "Wage dispersion between and within U.S manufacturing plants, 1963-86," Brookings Papers on Economic Activity, Microeconomics, 115180.

DEEG Richard \& JACKSON Gregory (2007), Towards a More Dynamic Theory of Capitalist Variety, Socio-Economic Review, 5(1), 149-179.

DEL GATTO, Massimo, OTTAVIANO, Gianmarco and PAGNINI, Marcello (2007), "Openness to trade and industry cost dispersion: Evidence from a panel of Italian firms," Discussion Paper 6336, Centre for Economic Policy Research. 
DUNNE, Timothy, FOSTER, Lucia, HALTIWANGER, John and TROSKE Kenneth (2004), "Wage and productivity dispersion in US manufacturing: The role of computer investment," Journal of Labor Economics 22(2): 397-430.

FAGGIO, Giulia, SALVANES, Kjell G. and VAN REENEN, John (2007), "The evolution of inequality in productivity and wages: Panel data evidence," CEP Discussion Paper 821, Centre for Economic Performance, London School of Economics.

FUKAO, Kyoji and KWON, Hyeog Ug (2006), "Why did Japan's TFP growth slow down in the lost decade? An empirical analysis based on firm-level data of manufacturing firms," Japanese Economic Review 57(2): 195-228.

FUNG ,Michael K. (2005), “Are knowledge spillovers driving the convergence of productivity among firms?” Economica 72(286): 287-305.

GOOD, David H., NADIRI, M. Ishaq, and SICKLES, Robin C. (1997), "Index number and factor demand approaches to the estimation of productivity,” in M. Hashem Pesaran and Peter Schmidt (eds.), Handbook of Applied Econometrics: Microeconomics, vol. II, Oxford: Blackwell.

HEAD, Keith and RIES, John (2003), "Heterogeneity and the FDI versus export decision of Japanese manufacturers," Journal of the Japanese and International Economies 17(4): 448-467.

HALTIWANGER, John, JARMIN, Ron S. and SCHANK, Thorsten (2003), "Productivity, investment in ICT and market experimentation: Micro evidence from Germany and the US," Working Paper 03-06, Center for Economic Studies, US Census Bureau.

HELPMAN, Elhanan (2006), “Trade, FDI, and the organization of firms," Journal of Economic Literature 44(3): 589-630.

HELPMAN, Elhanan, MELITZ, Marc J. and YEAPLE, Stephan R. (2004), "Export versus FDI with Heterogeneous Firms," American Economic Review 94(1): 300-316.

KIMURA, Fukunari and KIYOTA, Kozo (2006), "Exports, FDI, and Productivity: Dynamic Evidence from Japanese Firms,” Review of World Economics 142(4): 695-719.

KIYOTA, Kozo (2006), "Reconsidering the effects of intranational and international R\&D spillovers on productivity growth: Firm-level evidence from Japan,” RIETI Discussion Paper Series 06-E-001, Research Institute of Economy, Trade and Industry.

LECHEVALIER, Sébastien (2007), "The diversity of capitalism and heterogeneity of firms: A case study of Japan during the Lost Decade," Evolutionary and Institutional Economics Review 4(1): 113-142.

LEONARDI, Marco (2007), "Firm heterogeneity in capital/labor ratios and wage inequality," Economic Journal 117(518): 375-398.

MELITZ, Marc J. (2003), "The impact of trade on intra-industry reallocations and aggregate industry productivity,” Econometrica 71(6): 1695-1725.

MORIKAWA, Masayuki (2004), "Nihon kigyo no gyoseki kakusa to ukishizumi? Kigyo Katsudo Kihon Chosa maikuro deta ni yoru kensho" [The gap and volatility of performance of Japanese firms: Evidence from the micro-data underlying the Basic Survey of Japanese Business Structure and Activities], Chosa Working Paper WP05-01, Ministry of Economy, Trade and Industry (in Japanese). 
MORIKAWA, Masayuki (2007), "Sabisu sangyo no seisansei wa hikui no ka? Kigyo deta ni yoru seisansei no bunpu, dotai no bunseki" [Is productivity in the service industries low? An analysis using firm-level data on the dispersion and the dynamics of productivity], RIETI Discussion Paper Series 07-J-048, Research Institute of Economy, Trade and Industry (in Japanese).

MORTENSEN, Dale T. (2003), Wage Dispersion: Why are similar workers paid differently?, Cambridge, MA. and London: MIT Press.

MOTOHASHI, Kazuyuki (2008), "Comparative analysis of IT management and productivity between Japanese and U.S. firms" (sic), RIETI Discussion Paper Series 08-E-007, Research Institute of Economy, Trade and Industry.

NELSON, Richard R. (1981), "Research on productivity growth and productivity differences: Dead ends and new departures,” Journal of Economic Literature 19(3): 1029-1064.

NELSON, Richard R. (1991), "Why do firms differ, and how does it matter?" Strategic Management Journal, 12(Special Issue): 61-74.

NISHIMURA, Kiyohiko G., NAKAJIMA, Takanobu and KIYOTA, Kozo (2005), "Does the natural selection mechanism still work in severe recessions? Examination of the Japanese economy in the 1990s," Journal of Economic Behavior and Organization 58(1): 53-78.

SHINADA, Naoki (2003), "Decline in productivity in Japan and disparities between firms in the 1990s: An empirical approach based on data envelopment analysis" (sic), Research Report 38, Development Bank of Japan.

SYVERSON, Chad (2004a), “Market structure and productivity: A concrete example,” Journal of Political Economy 70(6): 1181-1222.

SYVERSON, Chad (2004b), "Product substitutability and productivity dispersion," Review of Economics and Statistics 86(2): 534-550. 


\section{Tables and figures}

\section{Table 1: JIP 2006 micro-data classification}

\begin{tabular}{|c|c|}
\hline 1 & Food products \\
\hline 2 & Textile products \\
\hline 3 & Lumber and wood products and furniture \\
\hline 4 & Pulp, paper, and coated and glazed paper \\
\hline 5 & Printing and publishing \\
\hline 6 & Chemicals and chemical fibers \\
\hline 7 & Paint, coating, and grease \\
\hline 8 & Pharmaceutical products \\
\hline 9 & Miscellaneous chemical products \\
\hline 10 & Petroleum and coal products \\
\hline 11 & Plastic products \\
\hline 12 & Rubber products \\
\hline 13 & Ceramic, stone and clay products \\
\hline 14 & Iron and steel \\
\hline 15 & Non-ferrous metals \\
\hline 16 & Fabricated metal products \\
\hline 17 & Metal processing machinery \\
\hline 18 & Special industry machinery \\
\hline 19 & Office and service industry machines \\
\hline 20 & Miscellaneous machinery \\
\hline 21 & Electrical generating, transmission, distribution and industrial apparatus \\
\hline 22 & Household electric appliances \\
\hline 23 & Communication equipment \\
\hline 24 & Computer equipment and accessories and electronic equipment \\
\hline 25 & Electronic parts and devices \\
\hline 26 & Miscellaneous electrical machinery equipment \\
\hline 27 & Motor vehicles and parts \\
\hline 28 & Other transportation equipment \\
\hline 29 & Precision machinery and equipment \\
\hline 30 & Miscellaneous manufacturing industries \\
\hline 31 & Agriculture, forestry, and fisheries \\
\hline 32 & Mining \\
\hline 33 & Construction \\
\hline 34 & Electricity, gas, heat supply \\
\hline 35 & Transportation and telecommunication services \\
\hline 36 & Wholesale trade \\
\hline 37 & Retail trade \\
\hline 38 & Finance \\
\hline 39 & Eating and drinking places \\
\hline 40 & Other services \\
\hline From 1 to 30 & Manufacturing \\
\hline $35+36+37+39$ & Non-manufacturing \\
\hline $\begin{array}{c}\text { From } 1 \text { to } \\
30+35+36+37+39\end{array}$ & Total \\
\hline
\end{tabular}


Figure 1(a): Evolution of the labor productivity dispersion in manufacturing (19942003)

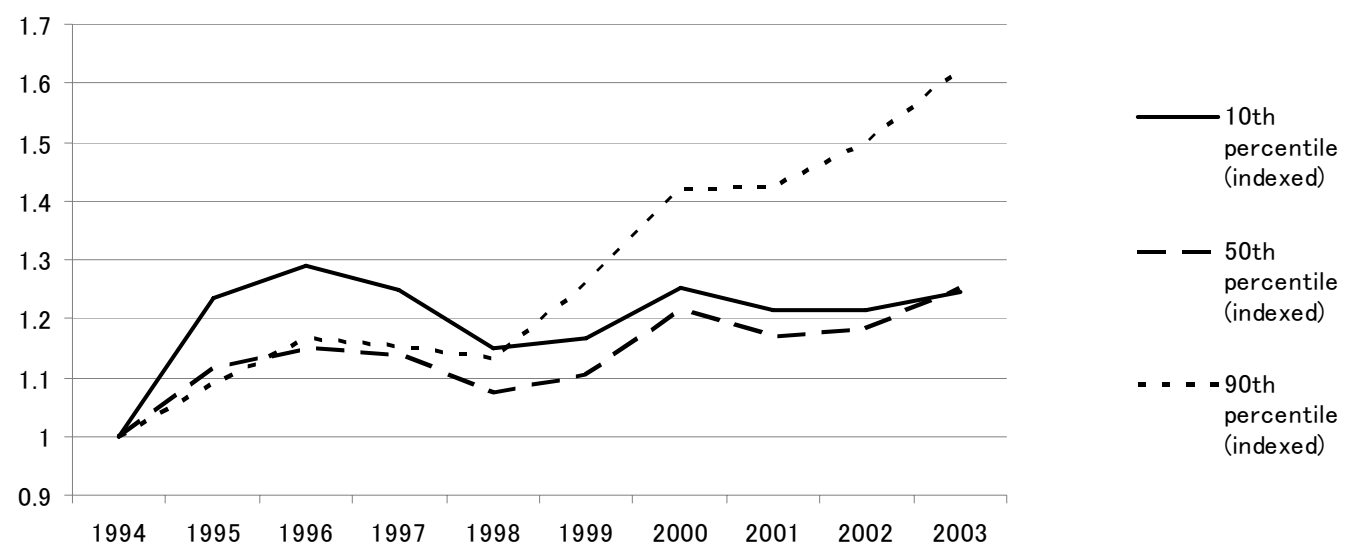

Figure 1(b): Evolution of the labor productivity dispersion in non-manufacturing (1994-2003)

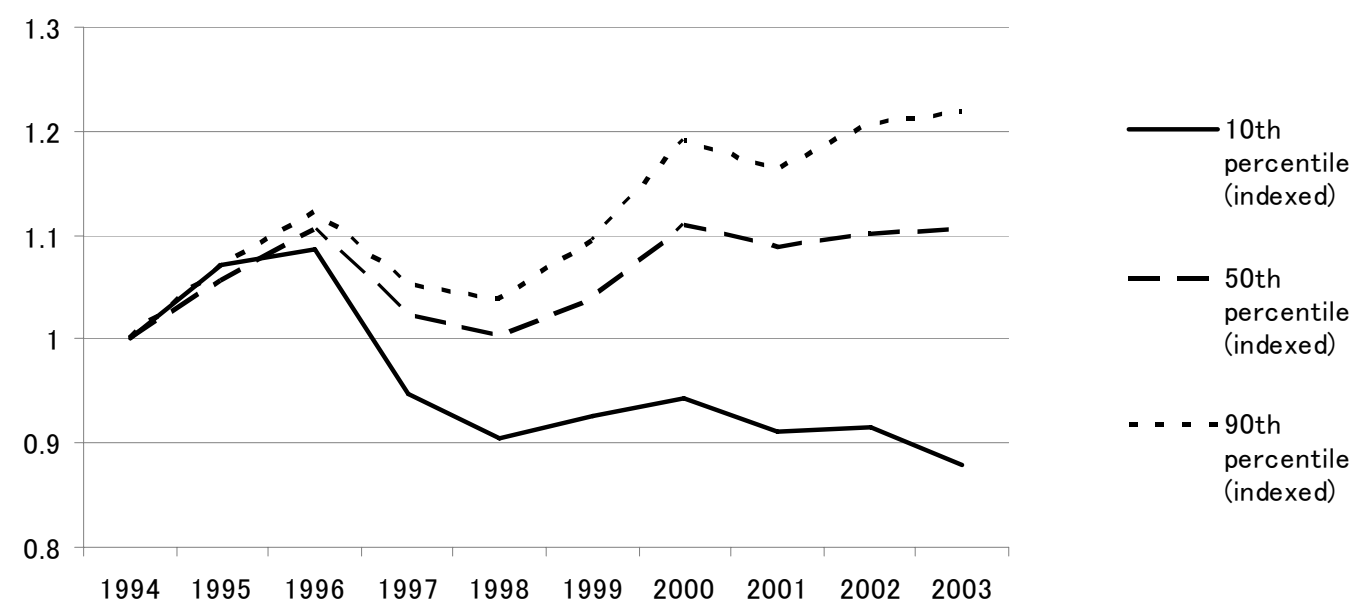


Figure 2(a): Evolution of the TFP dispersion in manufacturing (1994-2003)

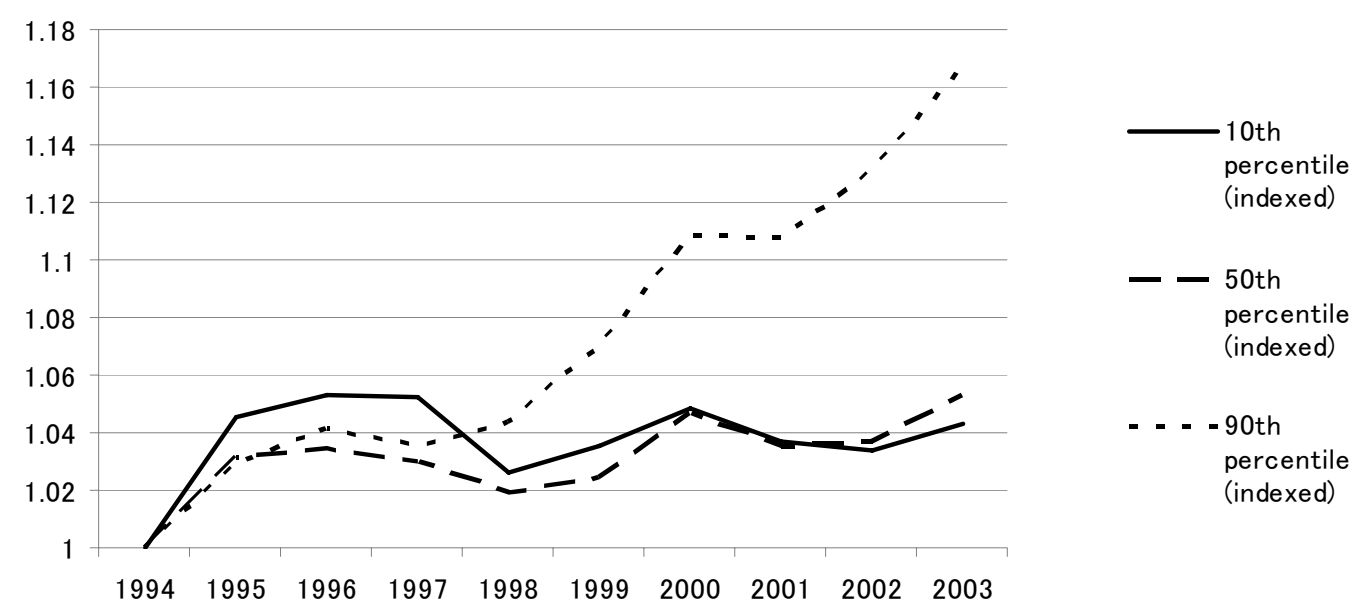

Figure 2(b): Evolution of the TFP dispersion in non-manufacturing (1994-2003

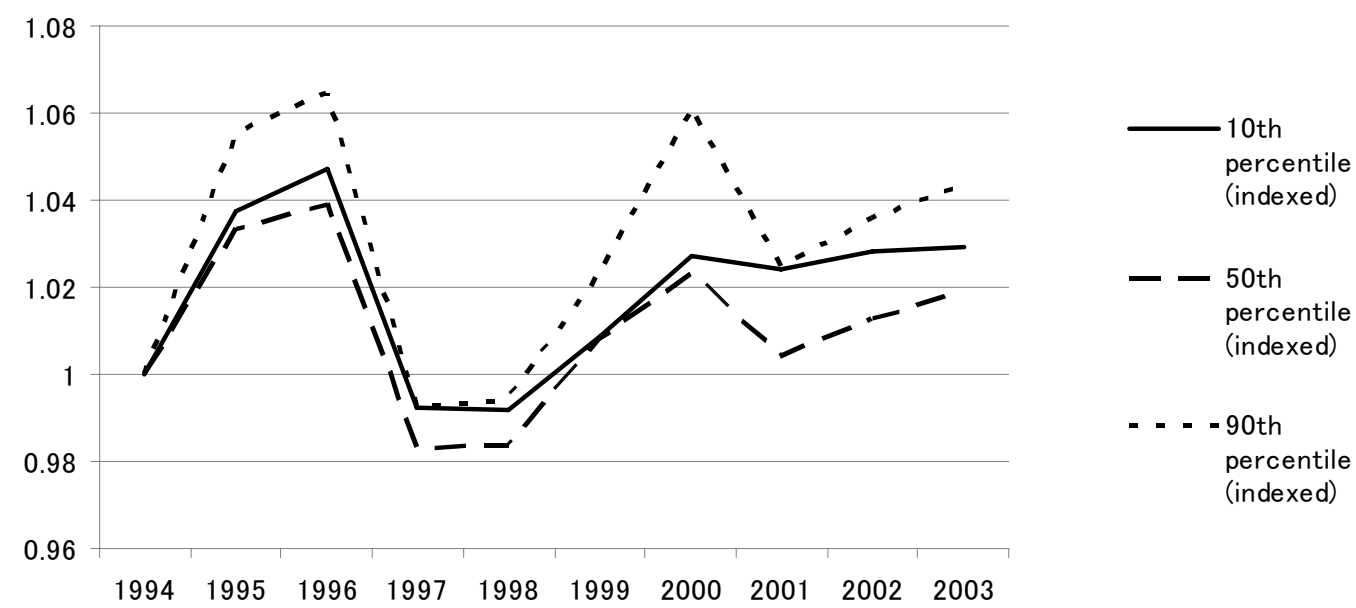


Figure 3(a): Decomposition of real labor productivity dispersion in manufacturing (1994-2003)

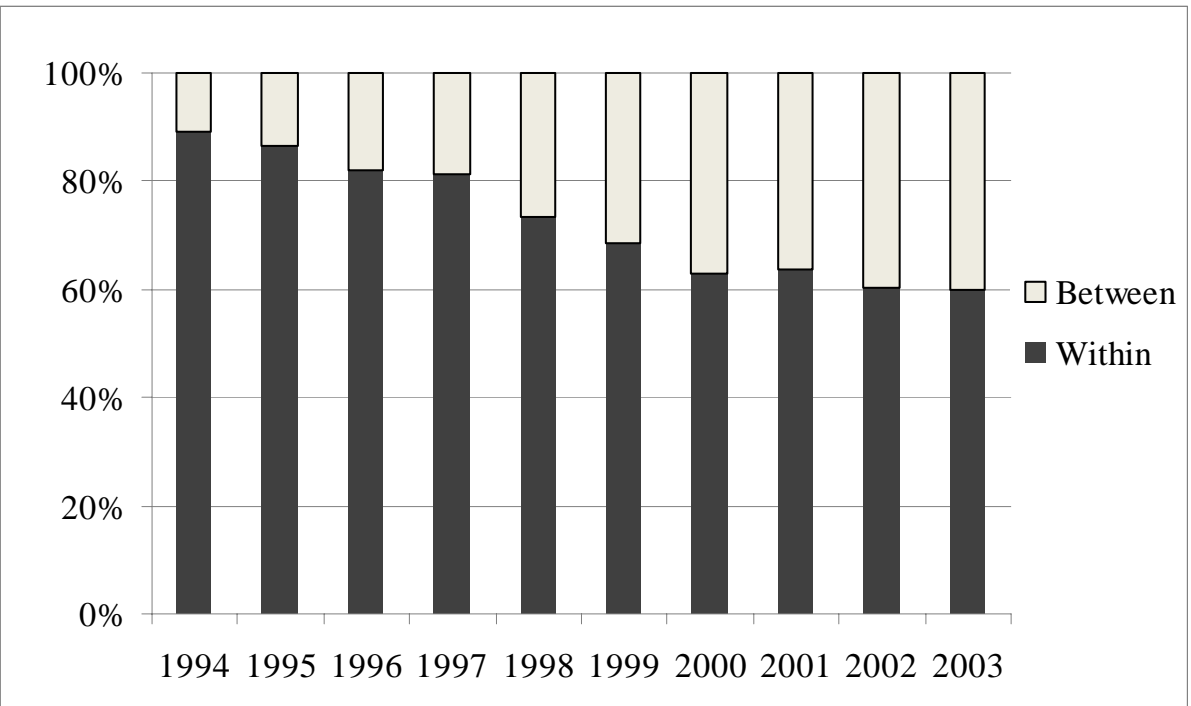

Figure 3(b): Decomposition of nominal labor productivity dispersion in manufacturing (1994-2003)

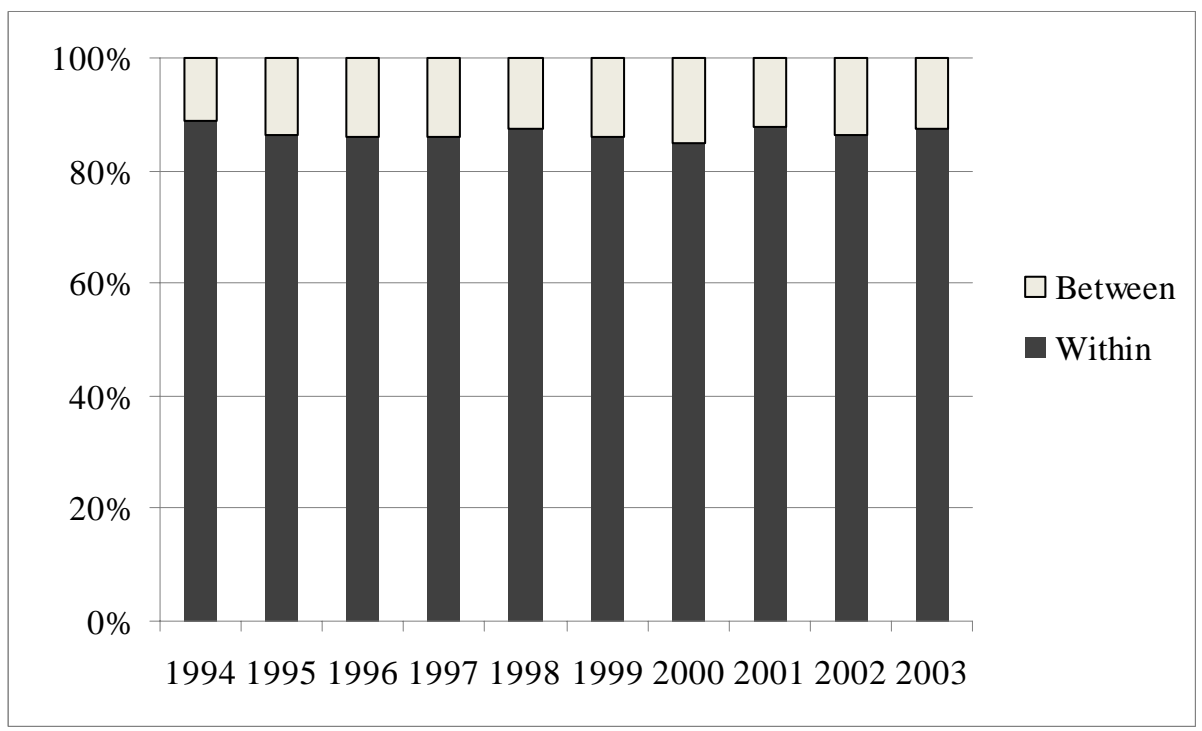


Figure 4(a): Evolution of the dispersion of labor productivity (distance between the first quartile and the last quartile), the IT ratio, $R \& D$ intensity, and the KL ratio between 1994-1998 and 1999-2003 by industry

Change in Log labor productivity dispersion

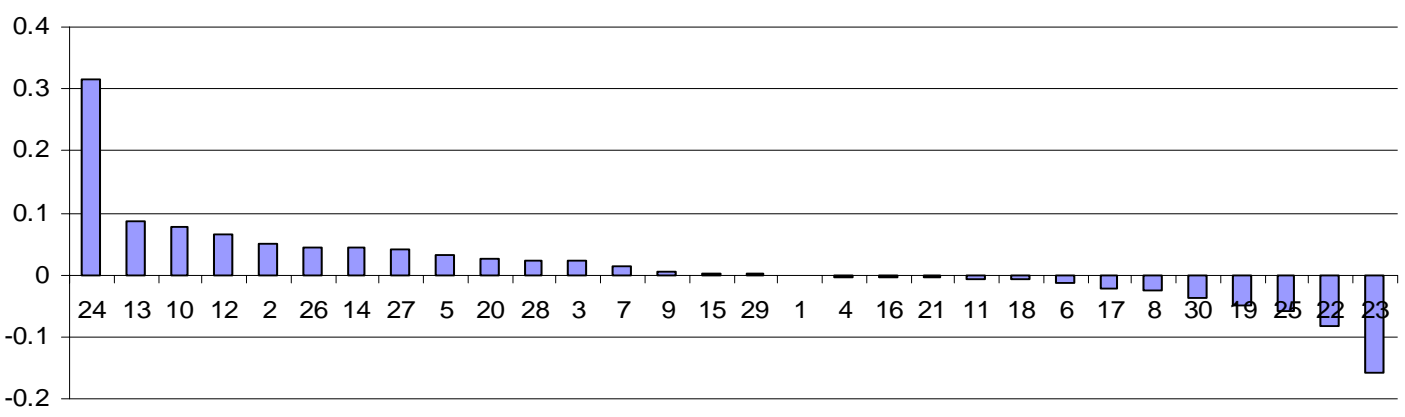

Change in IT ratio

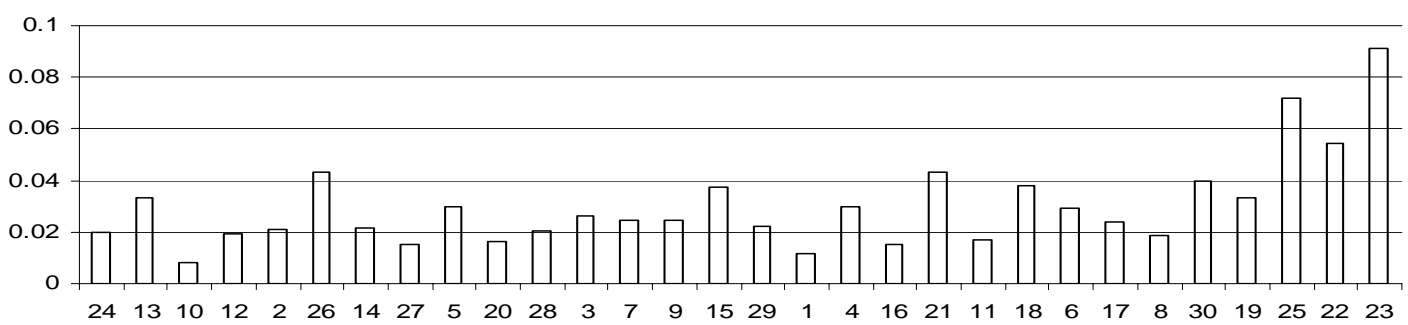

Change in R\&D intensity

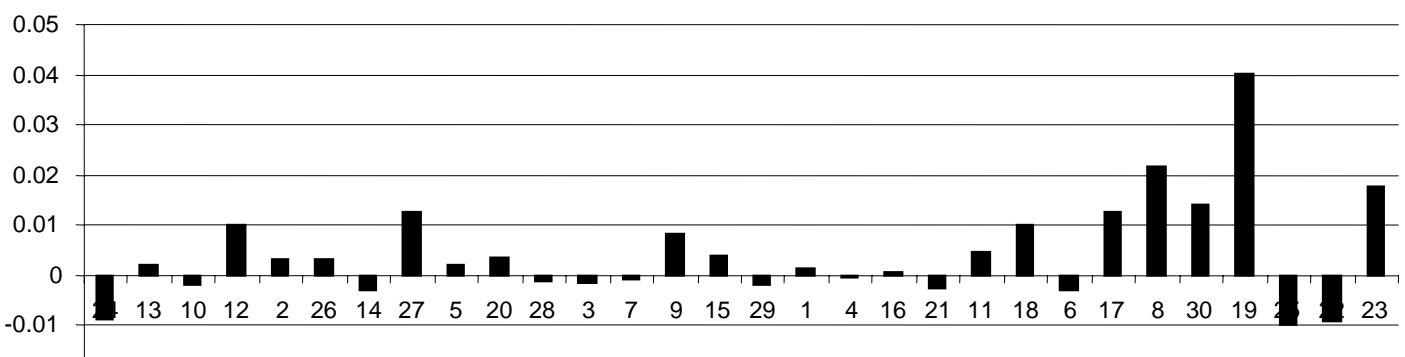
$-0.02$

Change in Log $\mathrm{KL}$ ratio

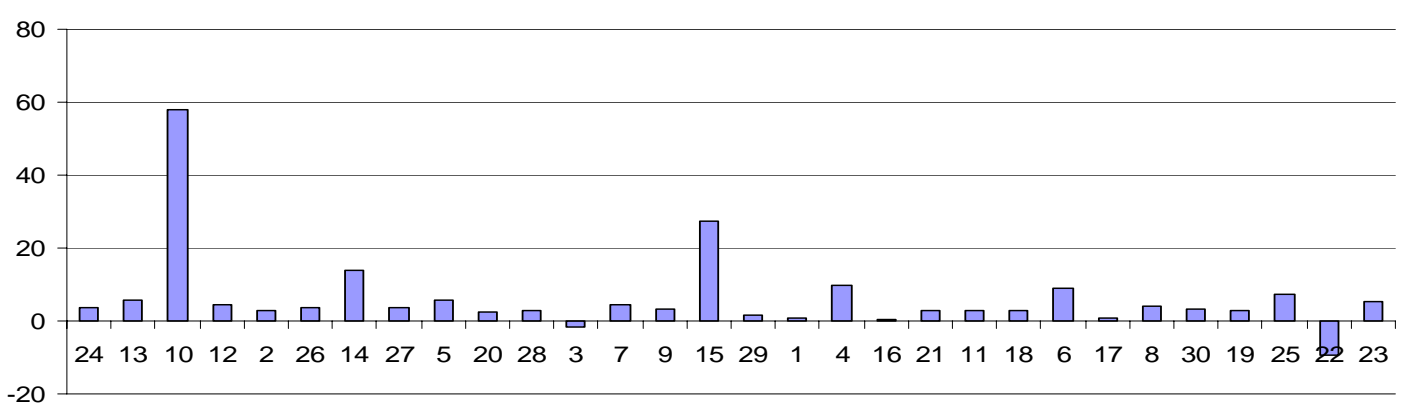


Figure 4(b): Evolution of the dispersion of labor productivity (distance between the first quartile and the last quartile), the Herfindahl index, import penetration, and export intensity between 1994-1998 and 1999-2003 by industry

Change in Log labor productivity dispersion

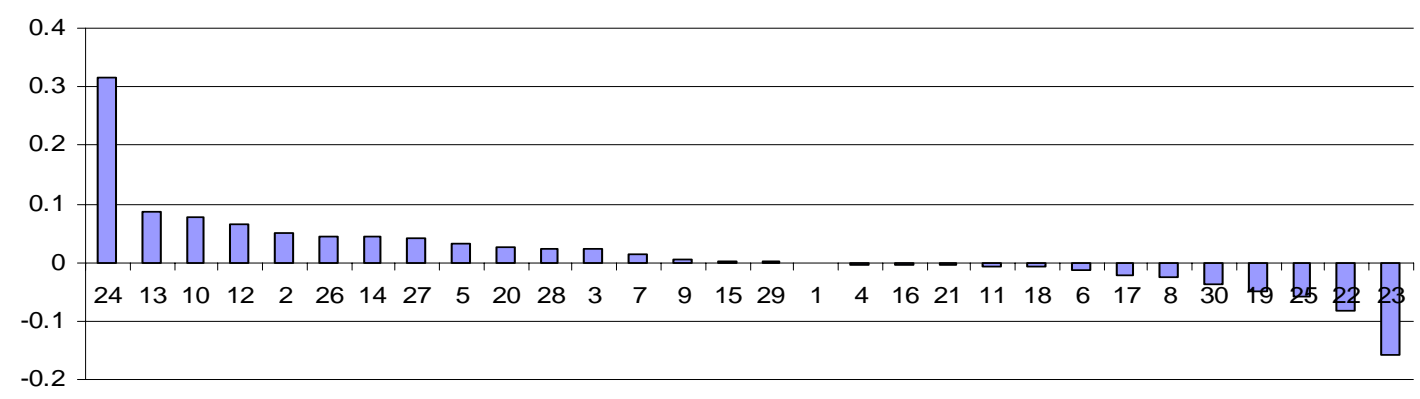

Change in Herfindahl index

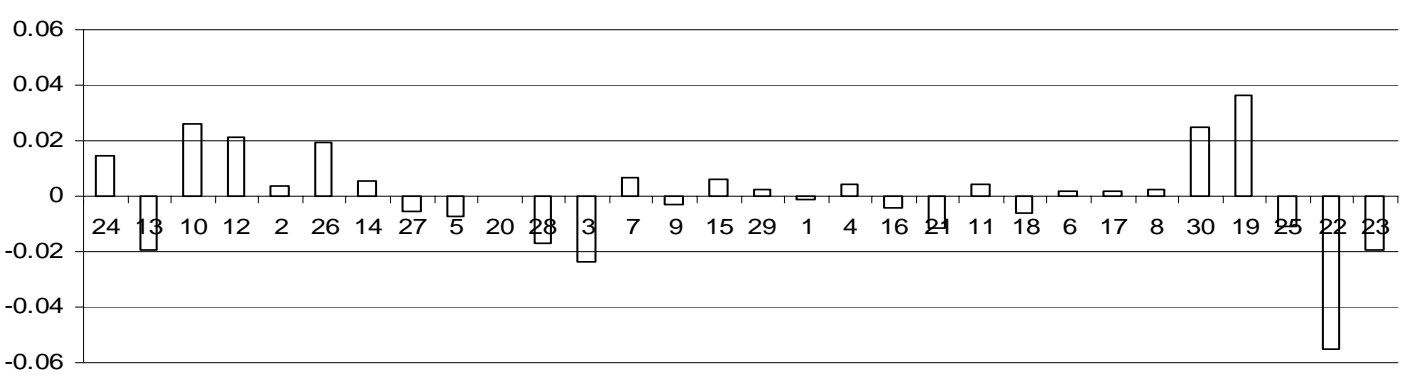

Change in import penetration

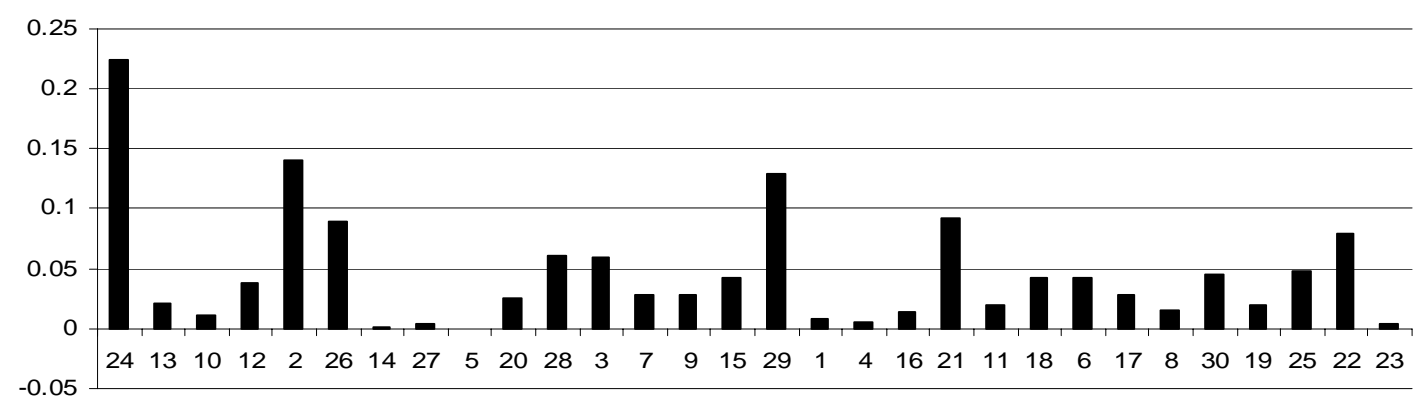

Change in export ratio

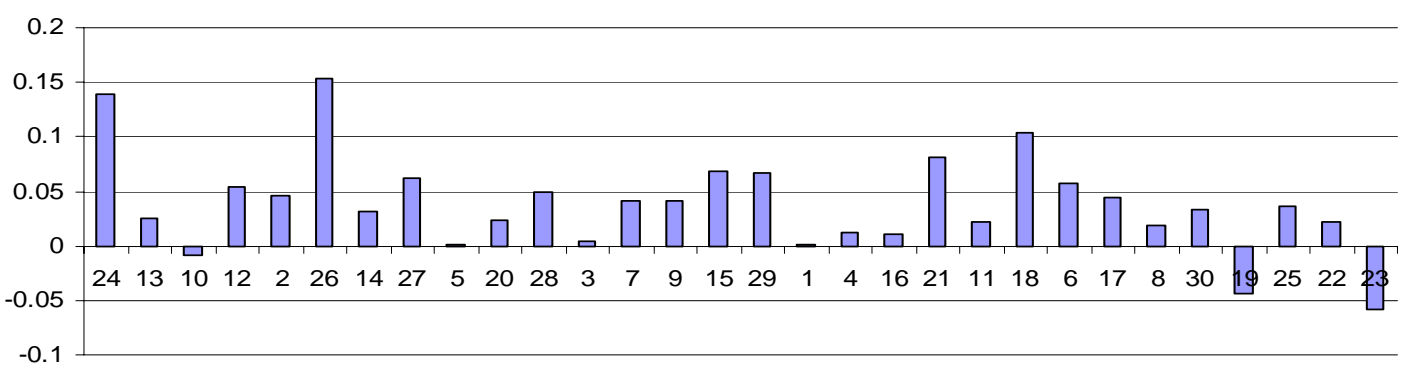


Figure 4(c): Evolution of the dispersion of TFP (distance between the first quartile and the last quartile), the IT ratio, R\&D intensity and the KL ratio between 19941998 and 1999-2003 by industry

Change in Log TFP dispersion

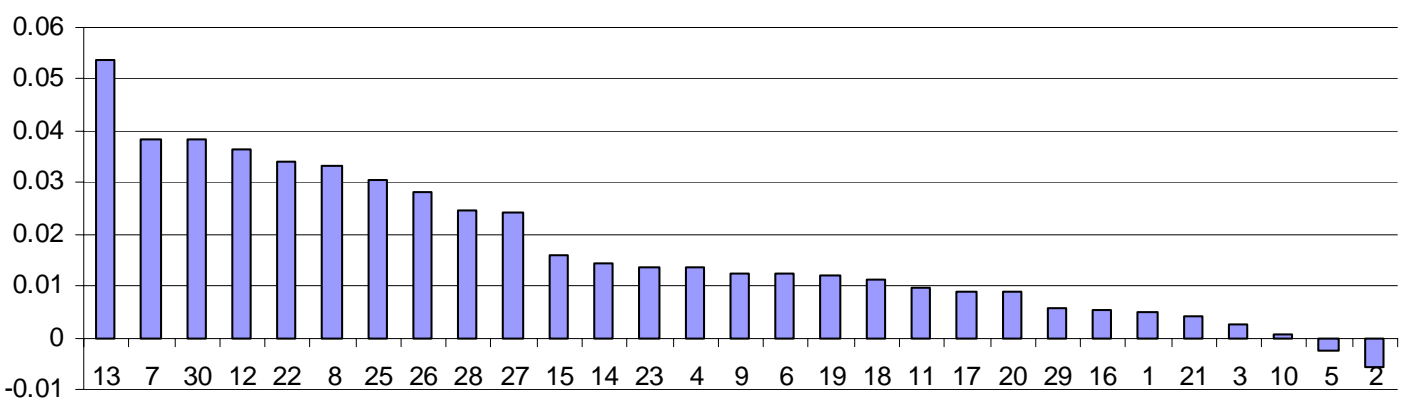

Change in IT ratio

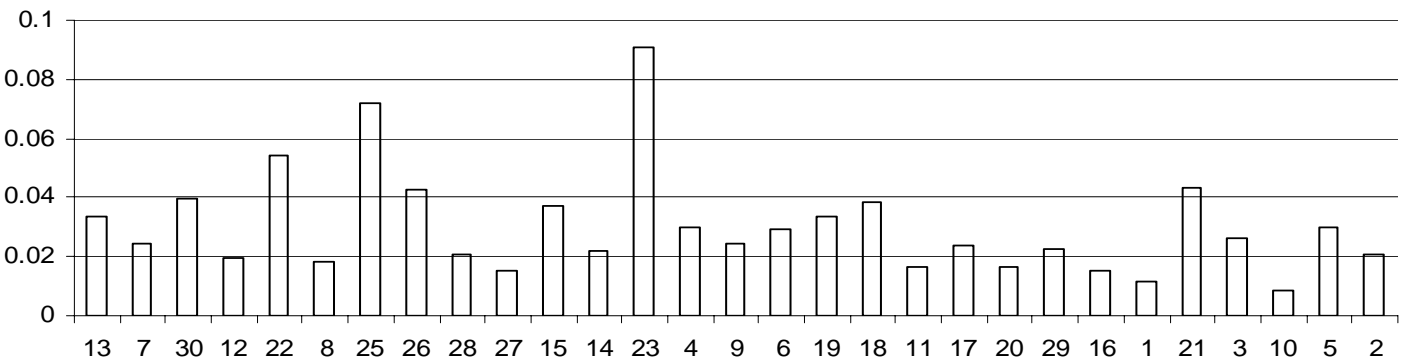

Change in R\&D intensity

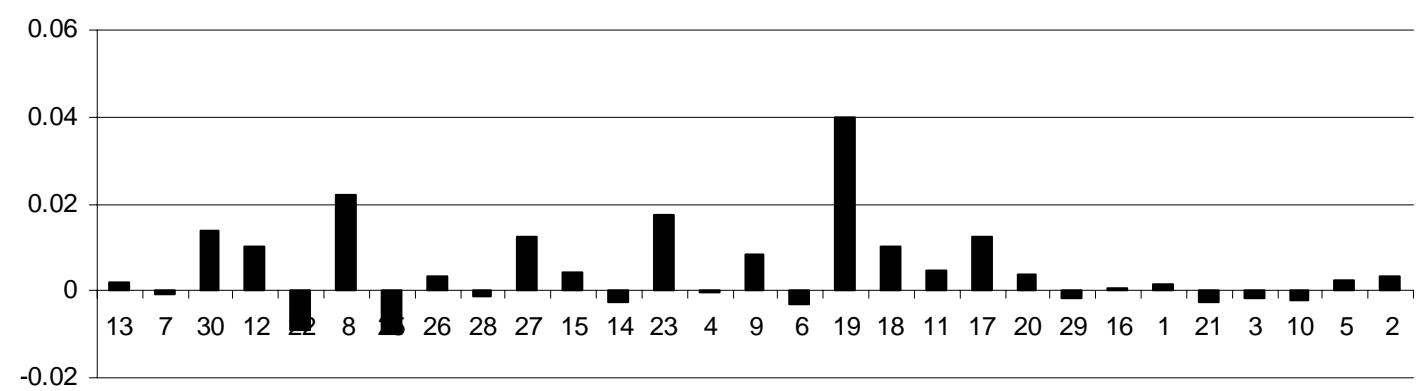

Change in Log KL ratio

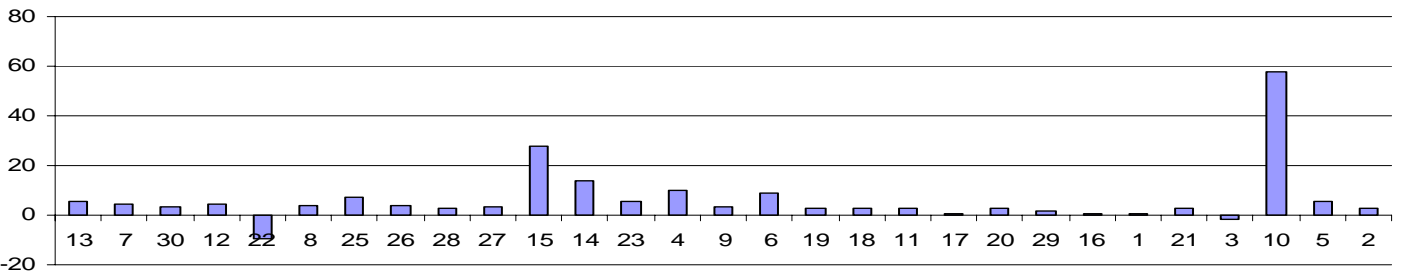

Note: Industry 24 has been excluded from the sample as it appears as an outlier from the point of view of change in TFP (six times larger than industry 13 which experienced the second largest change). 
Figure 4(d): Evolution of the dispersion of TFP (distance between the first quartile and the last quartile), Herfindahl index, import penetration, and export intensity between 1994-1998 and 1999-2003 by industry

Change in Log TFP dispersion

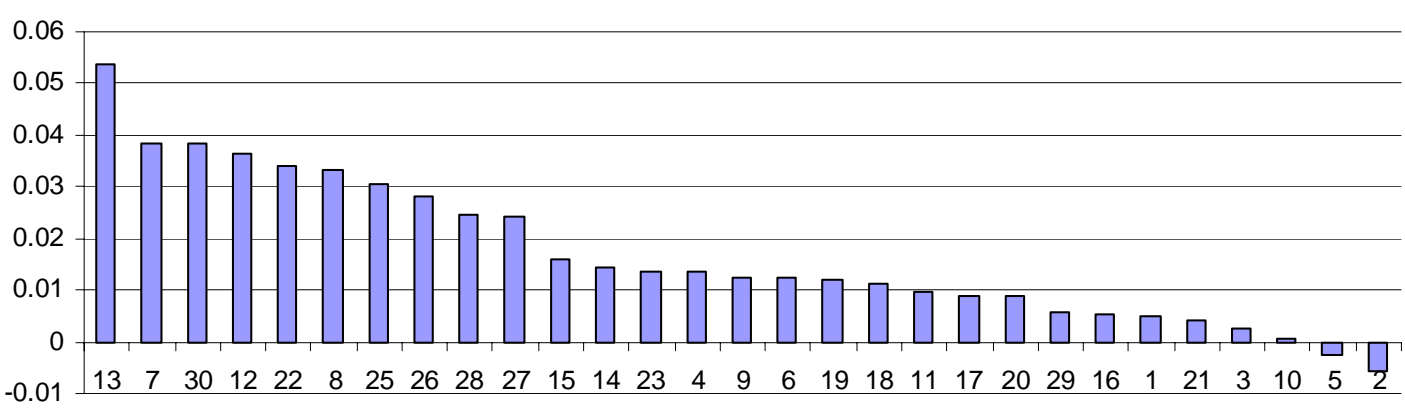

Change in Herfindahl index

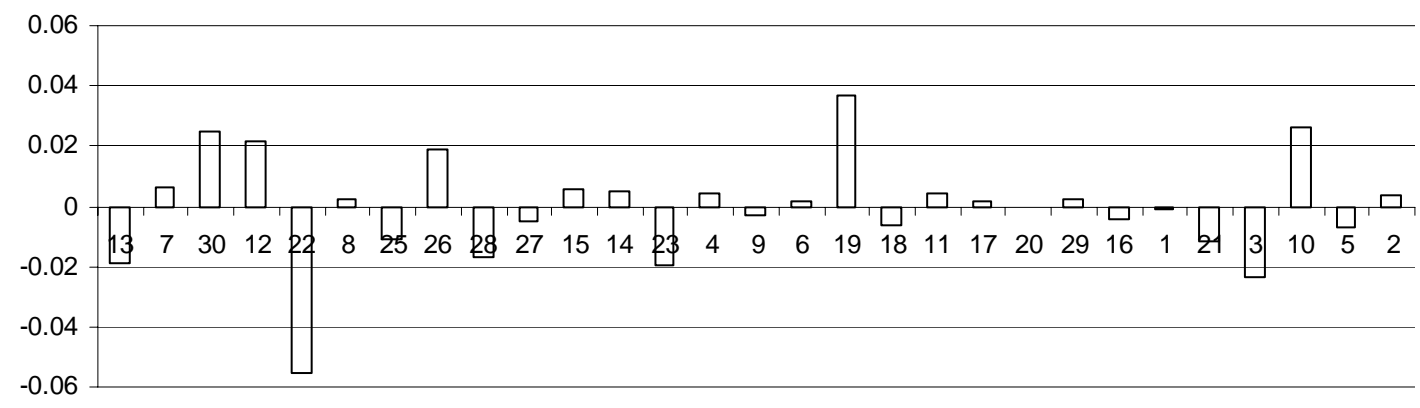

Change in import penetration

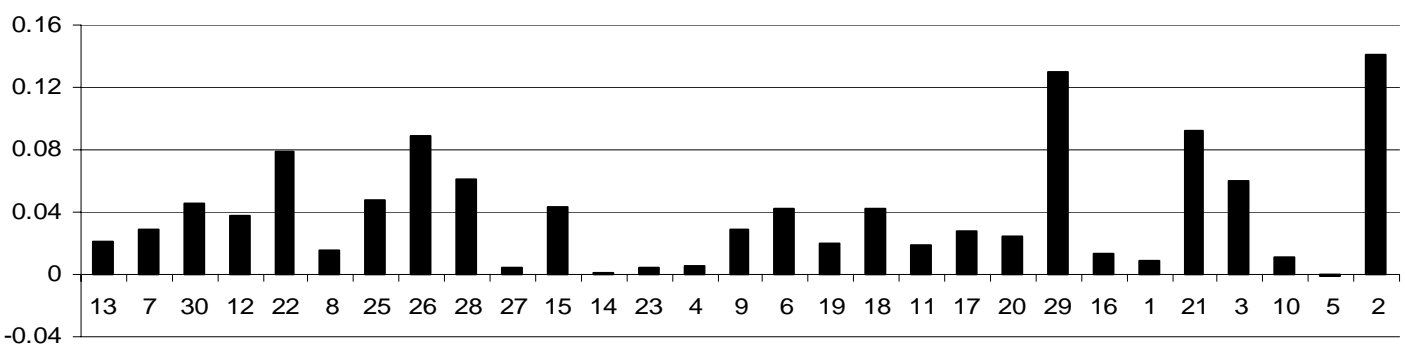

Change in export ratio

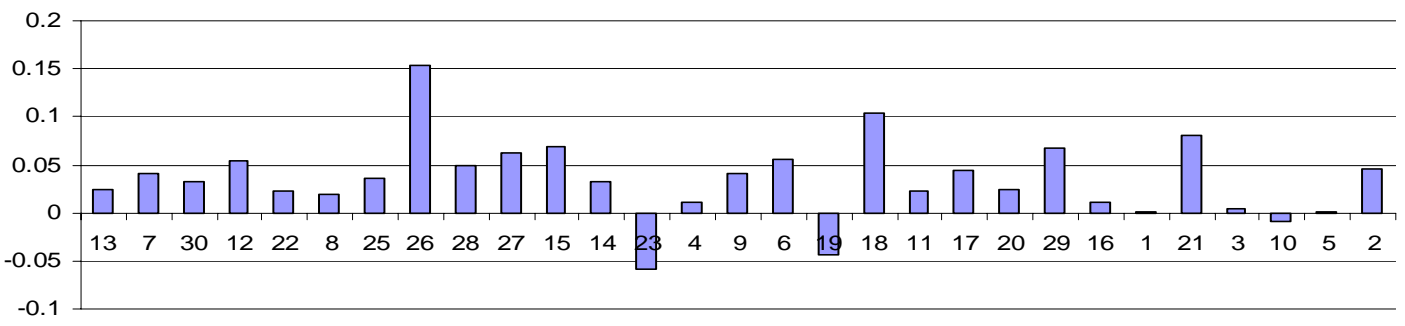

Note: Industry 24 has been excluded from the sample as it appears as an outlier from the point of view of change in TFP (six times larger than industry 13 which experienced the second largest change). 
Table 2: Definitions of variables

\begin{tabular}{|c|c|c|}
\hline Variables & Definition & Sources \\
\hline$\overline{I Q \ln V A P}$ & $\begin{array}{l}\text { Inter-quartile productivity difference (difference between the } \\
\text { 75th and 25th productivity percentiles): logarithm of value } \\
\text { added per employee }\end{array}$ & BSBSA \\
\hline$I D \ln V A P$ & $\begin{array}{l}\text { Inter-decile productivity difference (difference between the 90th } \\
\text { and 10th productivity percentiles): logarithm of value added per } \\
\text { employee }\end{array}$ & BSBSA \\
\hline$I Q \ln T F P$ & $\begin{array}{l}\text { Inter-quartile productivity difference (difference between the } \\
\text { 75th and 25th productivity percentiles): logarithm of TFP }\end{array}$ & BSBSA \\
\hline$I D \ln T F P$ & $\begin{array}{l}\text { Inter-decile productivity difference (difference between the 90th } \\
\text { and 10th productivity percentiles): logarithm of TFP }\end{array}$ & BSBSA \\
\hline $\ln V A P 50$ & Median productivity: logarithm of value added per employee & BSBSA \\
\hline $\operatorname{lnTFP50}$ & Median productivity: logarithm of TFP & BSBSA \\
\hline$R \& D$ intensity & R\&D intensity, calculated as R\&D expenditure divided by sales & BSBSA \\
\hline IT ratio & $\begin{array}{l}\text { ICT capital stock ratio, calculated as the real ICT capital stock } \\
\text { divided by the sum of real ICT capital stock and real non-ICT } \\
\text { capital stock }\end{array}$ & JIP \\
\hline ADV intensity & $\begin{array}{l}\text { Advertising intensity, calculated as the ratio of advertising } \\
\text { expenditure to sales }\end{array}$ & BSBSA \\
\hline$H H I$ & $\begin{array}{l}\text { Hershman-Herfindahl Index, calculated as the sum of each firm' } \\
\text { s sales share }\end{array}$ & BSBSA \\
\hline$I M P P E N$ & $\begin{array}{l}\text { Import penetration ratio, calculated as the ratio of industry } \\
\text { product imports to domestic demand }\end{array}$ & JIP \\
\hline EXPINT & $\begin{array}{l}\text { Export intensity, calculated as the ratio of exports to domestic } \\
\text { output }\end{array}$ & JIP \\
\hline KL ratio & $\begin{array}{l}\text { Capital-labor ratio, calculated as the real capital stock divided by } \\
\text { the number of employees (million yen per person) }\end{array}$ & BSBSA \\
\hline SURVRT & $\begin{array}{l}\text { Survival rate, calculated as the ratio of number of firms which } \\
\text { continued operating in the next vear to the total number of firms }\end{array}$ & BSBSA \\
\hline
\end{tabular}


Table 3: Regression results (Labor productivity dispersion)

Productivity measure: Log of real value added per employee

\begin{tabular}{|c|c|c|c|c|c|c|}
\hline & \multicolumn{4}{|c|}{ Productivity dispersion regressions } & \multirow{2}{*}{\multicolumn{2}{|c|}{$\begin{array}{c}\text { Central tendency regressions } \\
\text { Median lnVAP }\end{array}$}} \\
\hline & \multicolumn{2}{|c|}{ Inter-quartile range (IQlnVAP) } & \multicolumn{2}{|c|}{ 10th-90th percentiles (IDlnVAP) } & & \\
\hline & (1) & (2) & (3) & (4) & (5) & (6) \\
\hline R\&D intensity & $\begin{array}{r}0.4576 \\
(0.59)\end{array}$ & & $\begin{array}{r}0.8544 \\
(0.75)\end{array}$ & & $\begin{aligned} 2.9482 \\
(1.15)\end{aligned}$ & \\
\hline IT ratio & & $\begin{array}{l}-1.1672 * * \\
(-2.54)\end{array}$ & & $\begin{array}{l}-1.9258 * * * \\
(-2.85)\end{array}$ & & $\begin{array}{l}12.8490 * * * \\
\quad(9.63)\end{array}$ \\
\hline ADV intensity & $\begin{array}{r}-0.3130 \\
(-0.11)\end{array}$ & $\begin{array}{r}-0.0804 \\
(-0.03)\end{array}$ & $\begin{array}{r}-1.8769 \\
(-0.46)\end{array}$ & $\begin{array}{r}-1.4840 \\
(-0.37)\end{array}$ & $\begin{array}{c}19.7696 * * \\
(2.15)\end{array}$ & $\begin{array}{l}17.9534 * * \\
(2.27)\end{array}$ \\
\hline HHI & $\begin{array}{c}0.6145 \\
(2.28)\end{array}$ & $\begin{array}{l}0.6167 \\
(2.74)\end{array}$ & $\begin{array}{l}0.9648^{* *} \\
(2.43)\end{array}$ & $\begin{array}{l}0.9877 * * * \\
(2.99)\end{array}$ & $\begin{array}{c}-2.0130 \\
(-2.24)\end{array}$ & $\begin{array}{r}-0.4965 \\
(-0.76)\end{array}$ \\
\hline IMPPEN & $\begin{array}{l}0.5365 * * * \\
(2.70)\end{array}$ & $\begin{array}{l}0.4797 * * \\
(2.48)\end{array}$ & $\begin{array}{l}0.8542 * * * \\
(2.93)\end{array}$ & $\begin{array}{l}0.7559 * * * \\
(2.67)\end{array}$ & $\begin{array}{l}2.6790 * * * \\
(4.05)\end{array}$ & $\begin{array}{l}2.9286 * * * \\
(5.23)\end{array}$ \\
\hline EXPINT & $\begin{array}{l}0.5020 * * * \\
(2.83)\end{array}$ & $\begin{array}{l}0.4406 * * \\
(2.53)\end{array}$ & $\begin{array}{l}0.6155 * * \\
(2.36)\end{array}$ & $\begin{array}{l}0.5107 * * \\
(2.00)\end{array}$ & $\begin{array}{l}-1.9666 * * * \\
(-3.32)\end{array}$ & $\begin{array}{l}-1.5789 * * * \\
(-3.13)\end{array}$ \\
\hline KL ratio & $\begin{array}{l}0.0014 * * \\
(2.46)\end{array}$ & $\begin{array}{l}0.0012 \\
(2.18)\end{array}$ & $\begin{array}{c}0.0016 * \\
(1.88)\end{array}$ & $\begin{array}{r}0.0012 \\
(1.52)\end{array}$ & $\begin{array}{r}0.0010 \\
(0.51)\end{array}$ & $\begin{array}{r}0.0019 \\
(1.19)\end{array}$ \\
\hline No. of observations & 300 & 300 & 300 & 300 & 300 & 300 \\
\hline R squared & 0.2494 & 0.2668 & 0.2929 & 0.3133 & 0.3346 & 0.5096 \\
\hline F value & $5.65 * * *$ & $6.19 * * *$ & $7.04 * * *$ & $7.76 * * *$ & $8.55 * * *$ & $17.67 * * *$ \\
\hline
\end{tabular}

Notes: All equations include industry dummies and year dummies. $t$-values are in parentheses. $* * *, * *$, and $*$ indicate significance at the $1 \%, 5 \%$, and $10 \%$ level, respectively.

Table 4: Regression results (Labor productivity dispersion): Excluding computer equipment industry

\begin{tabular}{|c|c|c|c|c|c|c|}
\hline & \multicolumn{4}{|c|}{ Productivity dispersion regressions } & \multirow{2}{*}{\multicolumn{2}{|c|}{$\begin{array}{c}\text { Central tendency regressions } \\
\text { Median lnVAP }\end{array}$}} \\
\hline & \multicolumn{2}{|c|}{ Inter-quartile range (IQlnVAP) } & \multicolumn{2}{|c|}{ 10th-90th percentiles (IDlnVAP) } & & \\
\hline & $(1)$ & $(2)$ & (3) & $(4)$ & $(5)$ & (6) \\
\hline R\&D intensity & $\begin{array}{r}0.8069 \\
(1.07)\end{array}$ & & $\begin{aligned} 1.2421 \\
(1.14)\end{aligned}$ & & $\begin{array}{l}4.8921 * * \\
(2.13)\end{array}$ & \\
\hline IT ratio & & $\begin{array}{c}-1.0198 * * \\
(-2.28)\end{array}$ & & $\begin{array}{l}-1.7176 * * * \\
(-2.67)\end{array}$ & & $\begin{array}{c}13.10077^{* * *} \\
(11.87)\end{array}$ \\
\hline ADV intensity & $\begin{array}{r}-1.0365 \\
(-0.39)\end{array}$ & $\begin{array}{r}-0.7956 \\
(-0.30)\end{array}$ & $\begin{array}{r}-2.3857 \\
(-0.62)\end{array}$ & $\begin{array}{r}-1.9912 \\
(-0.52)\end{array}$ & $\begin{array}{c}17.7212 * * \\
(2.18)\end{array}$ & $\begin{array}{l}16.0852 * * \\
(2.46)\end{array}$ \\
\hline HHI & $\begin{array}{c}0.4551 \\
(1.72)\end{array}$ & $\begin{array}{l}0.5425 * * \\
(2.48)\end{array}$ & $\begin{array}{c}0.7497 * \\
(1.97)\end{array}$ & $\begin{array}{l}0.8739 * * * \\
(2.78)\end{array}$ & $\begin{array}{l}-2.6345 * * * \\
(-3.28)\end{array}$ & $\begin{array}{r}-0.7512 \\
(-1.39)\end{array}$ \\
\hline IMPPEN & $\begin{array}{r}0.0189 \\
(0.08)\end{array}$ & $\begin{array}{r}-0.0227 \\
(-0.10)\end{array}$ & $\begin{array}{r}0.3195 \\
(0.94)\end{array}$ & $\begin{array}{r}0.2530 \\
(0.76)\end{array}$ & $\begin{array}{r}0.4923 \\
(0.69)\end{array}$ & $\begin{array}{r}0.5633 \\
(0.99)\end{array}$ \\
\hline EXPINT & $\begin{array}{l}0.5368 * * * \\
(3.05)\end{array}$ & $\begin{array}{l}0.4621 * * * \\
(2.67)\end{array}$ & $\begin{array}{l}0.6840 \\
(2.69)\end{array}$ & $\begin{array}{l}0.5628 * * \\
(2.26)\end{array}$ & $\begin{array}{l}-2.0695 * * * \\
(-3.87)\end{array}$ & $\begin{array}{l}-1.7013 * * * \\
(-3.98)\end{array}$ \\
\hline KL ratio & $\begin{array}{c}0.0014 \\
(2.51)\end{array}$ & $\begin{array}{c}0.0011 \\
(2.12)\end{array}$ & $\begin{array}{c}0.0016 \\
(2.01)\end{array}$ & $\begin{array}{r}0.0012 \\
(1.57)\end{array}$ & $\begin{array}{r}0.0009 \\
(0.56)\end{array}$ & $\begin{array}{r}0.0016 \\
(1.21)\end{array}$ \\
\hline No. of observations & 290 & 290 & 290 & 290 & 290 & 290 \\
\hline R squared & 0.1772 & 0.1905 & 0.2479 & 0.2653 & 0.3774 & 0.5969 \\
\hline F value & $3.53 * * *$ & $3.86 * * *$ & $5.41 * * *$ & $5.92 * * *$ & $9.94 * * *$ & $24.29 * * *$ \\
\hline
\end{tabular}

Notes: All equations include industry dummies and year dummies. $t$-values are in parentheses. $* * *, * *$, and $*$ indicate significance at the $1 \%, 5 \%$, and $10 \%$ level, respectively. 
Table 5: Regression results (Labor productivity dispersion): Model controlling for survival rate

Productivity measure: Log of real value added per employee

\begin{tabular}{|c|c|c|c|c|c|c|}
\hline & \multicolumn{4}{|c|}{ Productivity dispersion regressions } & \multirow{2}{*}{\multicolumn{2}{|c|}{$\begin{array}{c}\text { Central tendency regressions } \\
\text { Median lnVAP }\end{array}$}} \\
\hline & \multicolumn{2}{|c|}{ Inter-quartile range (IQlnVAP) } & \multicolumn{2}{|c|}{ 10th-90th percentiles (IDlnVAP) } & & \\
\hline & $(1)$ & (2) & (3) & (4) & (5) & (6) \\
\hline R\&D intensity & $\begin{array}{r}0.6343 \\
(0.73)\end{array}$ & & $\begin{array}{r}1.2595 \\
(1.01)\end{array}$ & & $\begin{array}{r}3.3242 \\
(1.28)\end{array}$ & \\
\hline IT ratio & & $\begin{array}{l}-1.5631 * * * \\
(-2.97)\end{array}$ & & $\begin{array}{c}-2.5232 \\
(-3.32)\end{array}$ & & $\begin{array}{l}13.2537 * * * \\
\quad(9.76)\end{array}$ \\
\hline ADV intensity & $\begin{array}{r}-0.2660 \\
(-0.08)\end{array}$ & $\begin{array}{r}-0.3377 \\
(-0.11)\end{array}$ & $\begin{array}{r}-0.2430 \\
(-0.05)\end{array}$ & $\begin{array}{l}-0.3682 \\
(-0.08)\end{array}$ & $\begin{array}{r}14.8330 \\
(1.56)\end{array}$ & $\begin{array}{c}15.0936 * \\
(1.89)\end{array}$ \\
\hline HHI & $\begin{array}{l}0.7010 * * \\
(2.17)\end{array}$ & $\begin{array}{l}0.7235 * * * \\
(2.78)\end{array}$ & $\begin{array}{l}1.0939 * * \\
(2.34)\end{array}$ & $\begin{array}{l}1.18144^{* * * *} \\
(3.14)\end{array}$ & $\begin{array}{c}-2.1297 * * \\
(-2.19)\end{array}$ & $\begin{array}{r}-0.4239 \\
(-0.63)\end{array}$ \\
\hline IMPPEN & $\begin{array}{l}0.5343^{* *} \\
(2.25)\end{array}$ & $\begin{array}{l}0.4870^{* *} \\
(2.13)\end{array}$ & $\begin{array}{l}0.9966^{* * *} \\
(2.89)\end{array}$ & $\begin{array}{l}0.9069^{* * *} \\
(2.75)^{2}\end{array}$ & $\begin{array}{l}2.0265 \\
(2.83)\end{array}$ & $\begin{array}{l}1.9333^{* * *} \\
(3.27)\end{array}$ \\
\hline EXPINT & $\begin{array}{c}0.4802 \\
(2.25)\end{array}$ & $\begin{array}{c}0.4089 * \\
(1.96)\end{array}$ & $\begin{array}{c}0.5584 \\
(1.80)\end{array}$ & $\begin{array}{r}0.4362 \\
(1.45)\end{array}$ & $\begin{array}{l}-1.8704 * * * \\
(-2.91)\end{array}$ & $\begin{array}{l}-1.5269 * * * \\
(-2.83)\end{array}$ \\
\hline KL ratio & $\begin{array}{l}0.0016^{* *} \\
(2.47)\end{array}$ & $\begin{array}{c}0.0013^{* *} \\
(2.20)\end{array}$ & $\begin{array}{c}0.0018 * \\
(1.96)\end{array}$ & $\begin{array}{r}0.0014 \\
(1.58)\end{array}$ & $\begin{array}{r}0.0009 \\
(0.45)\end{array}$ & $\begin{array}{r}0.0013 \\
(0.86)\end{array}$ \\
\hline SURVRT & $\begin{array}{c}0.3161 \\
(2.06)\end{array}$ & $\begin{array}{c}0.3657 * * \\
(2.42)\end{array}$ & $\begin{array}{c}0.4351 * \\
(1.95)\end{array}$ & $\begin{array}{c}0.5184 * * \\
(2.37)\end{array}$ & $\begin{array}{r}-0.1201 \\
(-0.26)\end{array}$ & $\begin{array}{r}-0.4260 \\
(-1.09)\end{array}$ \\
\hline No. of observations & 270 & 270 & 270 & 270 & 270 & 270 \\
\hline $\mathrm{R}$ squared & 0.2335 & 0.2607 & 0.2995 & 0.3293 & 0.2993 & 0.5043 \\
\hline F value & $4.57 * * *$ & $5.29 * * *$ & $6.41 * * *$ & $7.37 * * *$ & $6.41 * * *$ & $15.26 * * *$ \\
\hline
\end{tabular}

Notes: All equations include industry dummies and year dummies. $t$-values are in parentheses. $* * *, * *$, and $*$ indicate significance at the 1\%, 5\%, and $10 \%$ level, respectively.

Table 6: Regression results (Labor productivity dispersion): Excluding computer equipment industry, Model controlling for survival rate

Productivity measure: Log of real value added per employee

\begin{tabular}{|c|c|c|c|c|c|c|}
\hline & \multicolumn{4}{|c|}{ Productivity dispersion regressions } & \multirow{2}{*}{\multicolumn{2}{|c|}{$\begin{array}{c}\text { Central tendency regressions } \\
\text { Median lnVAP }\end{array}$}} \\
\hline & \multicolumn{2}{|c|}{ Inter-quartile range (IQlnVAP) } & \multicolumn{2}{|c|}{ 10th-90th percentiles (IDlnVAP) } & & \\
\hline & (1) & (2) & (3) & (4) & (5) & (6) \\
\hline R\&D intensity & $\begin{aligned} 0.9906 \\
(1.16)\end{aligned}$ & & $\begin{array}{r}1.7445 \\
(1.45)\end{array}$ & & $\begin{array}{l}4.9561{ }^{* *} \\
(2.11)\end{array}$ & \\
\hline IT ratio & & $\begin{array}{l}-1.2861 * * \\
(-2.48)\end{array}$ & & $\begin{array}{l}-2.1187 \quad * * * \\
(-2.90)\end{array}$ & & $\begin{array}{c}13.8932 \\
(12.49)\end{array}$ \\
\hline ADV intensity & $\begin{array}{r}-0.5700 \\
(-0.19)\end{array}$ & $\begin{array}{r}-0.6449 \\
(-0.21)\end{array}$ & $\begin{array}{r}-0.2883 \\
(-0.07)\end{array}$ & $\begin{array}{r}-0.4170 \\
(-0.10)\end{array}$ & $\begin{array}{c}14.8414 * \\
(1.76)\end{array}$ & $\begin{array}{l}14.9311 * * \\
(2.30)\end{array}$ \\
\hline HHI & $\begin{array}{c}0.5287 * \\
(1.66)\end{array}$ & $\begin{array}{l}0.6619 * * \\
(2.59)\end{array}$ & $\begin{array}{c}0.8221 * \\
(1.83)\end{array}$ & $\begin{array}{l}1.0665 * * * \\
(2.97)\end{array}$ & $\begin{array}{l}-2.6066 * * * \\
(-2.98)\end{array}$ & $\begin{array}{r}-0.5739 \\
(-1.05)\end{array}$ \\
\hline IMPPEN & $\begin{array}{r}0.0516 \\
(0.19)\end{array}$ & $\begin{array}{r}0.0430 \\
(0.16)\end{array}$ & $\begin{array}{r}0.3843 \\
(0.99)\end{array}$ & $\begin{array}{r}0.3654 \\
(0.96)\end{array}$ & $\begin{array}{r}0.5294 \\
(0.70)\end{array}$ & $\begin{array}{r}-0.0452 \\
(-0.08)\end{array}$ \\
\hline EXPINT & $\begin{array}{l}0.5165 * * * \\
(2.41)\end{array}$ & $\begin{array}{l}0.4318 * * * \\
(2.05)\end{array}$ & $\begin{array}{l}0.6002 \\
(1.99)\end{array}$ & $\begin{array}{r}0.4567 \\
(1.54)\end{array}$ & $\begin{array}{c}-1.8400 * * * \\
(-3.12)\end{array}$ & $\begin{array}{l}-1.4589 \text { *** } \\
(-3.23)\end{array}$ \\
\hline KL ratio & $\begin{array}{l}0.0015 * * \\
(2.49)\end{array}$ & $\begin{array}{l}0.0013 * * \\
(2.13)\end{array}$ & $\begin{array}{l}0.0018 * * \\
(2.04)\end{array}$ & $\begin{array}{r}0.0013 \\
(1.56)\end{array}$ & $\begin{array}{r}0.0011 \\
(0.64)\end{array}$ & $\begin{array}{r}0.0013 \\
(1.02)\end{array}$ \\
\hline SURVRT & $\begin{array}{c}0.2589 * \\
(1.69)\end{array}$ & $\begin{array}{c}0.3068 * * \\
(2.02)\end{array}$ & $\begin{array}{r}0.3023 \\
(1.40)\end{array}$ & $\begin{array}{c}0.3827 * \\
(1.79)\end{array}$ & $\begin{array}{r}0.0697 \\
(0.17)\end{array}$ & $\begin{array}{r}-0.2530 \\
(-0.78)\end{array}$ \\
\hline No. of observations & 261 & 261 & 261 & 261 & 261 & 261 \\
\hline $\mathrm{R}$ squared & 0.1835 & 0.201 & 0.2615 & 0.2823 & 0.3489 & 0.6135 \\
\hline F value & $3.25 * * *$ & $3.64 * * *$ & $5.12 * * *$ & $5.69 * * *$ & $7.75 * * *$ & $22.96 * * *$ \\
\hline
\end{tabular}

Notes: All equations include industry dummies and year dummies. $t$-values are in parentheses. $* * *, * *$, and $*$ indicate significance at the 1\%, 5\%, and $10 \%$ level, respectively. 


\section{Appendix: Variable construction and data sources}

Output: Except for the commerce sector, gross output is defined as the total sales of firms. For the commerce sector, gross output is measured as sales minus expenses for purchased materials. Gross output is deflated by the output deflator taken from the JIP Database 2006.

Intermediate inputs: For the commerce sector, intermediate inputs are calculated as (Cost of sales + Operating costs) - (Wages + Depreciation costs + Expenses for purchased materials). The intermediate inputs of other sectors are defined as (Cost of sales + Operating costs) - (Wages + Depreciation costs). Intermediate inputs are deflated by the intermediate input deflator taken from the JIP Database 2006.

Labor input: As labor input, we used each firm's total number of workers multiplied by the sectoral working hours taken from the JIP Database 2006.

Capital Stock: For capital stock, the only data available are the nominal book values of tangible fixed assets. Using these data, we calculated the net capital stock of firm $i$ in industry $j$ in constant 1995 prices as follows:

$$
K_{i t}=B V_{i t} *\left(I N K_{j t} / I B V_{j t}\right)
$$

where $B V_{i t}$ represents the book value of firm $i$ 's tangible fixed assets in year $t, I N K_{j t}$ stands for the net capital stock of industry $j$ in constant 1995 prices, and $I B V_{j t}$ denotes the book value of industry $j$ 's capital. $I N K_{j t}$ was calculated as follows. First, as a benchmark, we took the data on the book value of tangible fixed assets in 1975 from the Financial Statements Statistics of Corporations published by the Ministry of Finance. We then converted the book value of year 1975 into the real value in constant 1995 prices using the investment deflator taken from the JIP Database 2006. Second, the net capital stock of industry $j, I N K_{j t}$, for succeeding years was calculated using the perpetual inventory method. The sectoral depreciation rate used is taken from the JIP Database 2006.

Cost Shares: Total cost of labor is measured as total wages. We used nominal intermediate input as the intermediate input cost. Capital cost was calculated by multiplying the real net capital stock with the user cost of capital. The latter was estimated as follows:

$$
c_{k}=\frac{1-z}{1-u} p_{k}\left\{\lambda r+(1-u)(1-\lambda) i+\delta_{i}-\left(\frac{\dot{p}_{k}}{p_{k}}\right)\right\}
$$

where $p_{k}, i, \delta, u, \lambda$ and $z$ are the price of investment goods, the interest rate, the depreciation rate, the corporate tax rate, the equity ratio, and the present value of depreciation deduction on a unit of nominal investment, respectively. Data on investment goods prices, interest rates, and corporate tax rates were taken from the JIP Database 2006, the Bank of Japan's website, and the Ministry of Finance Statistics Monthly, respectively. The depreciation rate for each sector was taken from the JIP Database 2006. We calculated the cost shares of each factor by dividing the cost of each factor by total costs, which consist of the sum of labor costs, intermediate inputs costs, and capital costs. 
Appendix Table 1: Summary statistics

\begin{tabular}{lrrrrr}
\hline \hline \multicolumn{1}{c}{ Variable } & \multicolumn{1}{c}{ Obs. } & \multicolumn{1}{c}{ Mean } & \multicolumn{1}{c}{ Std. Dev. } & \multicolumn{1}{c}{ Min. } & \multicolumn{1}{c}{ Max. } \\
\hline IQlnVAP & 300 & 0.3047 & 0.0997 & 0.1789 & 1.2148 \\
IDlnVAP & 300 & 0.5990 & 0.1682 & 0.3660 & 1.8966 \\
IQlnTFP & 300 & 0.1261 & 0.0547 & 0.0509 & 0.7255 \\
IDlnTFP & 300 & 0.2480 & 0.0759 & 0.1265 & 0.9305 \\
InVAP50 & 300 & 1.9651 & 0.3975 & 0.9888 & 3.7927 \\
InTFP50 & 300 & 0.0195 & 0.0994 & -0.1305 & 0.7888 \\
R\&D intensity & 300 & 0.0318 & 0.0238 & 0.0018 & 0.1259 \\
IT ratio & 300 & 0.1189 & 0.0601 & 0.0308 & 0.2839 \\
ADV intensity & 300 & 0.0089 & 0.0094 & 0.0006 & 0.0369 \\
HHI & 300 & 0.0581 & 0.0445 & 0.0075 & 0.2681 \\
IMPPEN & 300 & 0.1117 & 0.0879 & 0.0040 & 0.5333 \\
EXPINT & 300 & 0.1655 & 0.1257 & 0.0020 & 0.6224 \\
KL ratio & 300 & 22.9843 & 27.8027 & 6.2122 & 210.7628 \\
SURVRT & 290 & 0.8091 & 0.0655 & 0.4427 & 0.9450 \\
\hline \hline
\end{tabular}

Appendix Table 2: Correlation matrix

\begin{tabular}{|c|c|c|c|c|c|c|c|c|c|c|c|c|c|c|}
\hline & & (1) & $\overline{(2)}$ & (3) & (4) & (5) & (6) & $\overline{(7)}$ & $\overline{(28)}$ & (9) & (10) & (11) & $\overline{~(12) ~}$ & (13) \\
\hline (1) & IQlnTFP & 1 & & & & & & & & & & & & \\
\hline (2) & IDlnTFP & 0.941 & 1 & & & & & & & & & & & \\
\hline (3) & IQlnVAP & 0.451 & 0.441 & 1 & & & & & & & & & & \\
\hline (4) & IDlnVAP & 0.416 & 0.436 & 0.933 & 1 & & & & & & & & & \\
\hline (5) & $\operatorname{lnTFP50}$ & 0.358 & 0.411 & -0.104 & -0.166 & 1 & & & & & & & & \\
\hline (6) & $\operatorname{lnVAP50}$ & 0.237 & 0.200 & -0.150 & -0.310 & 0.745 & 1 & & & & & & & \\
\hline (7) & IT ratio & 0.241 & 0.354 & -0.024 & 0.004 & 0.423 & 0.121 & 1 & & & & & & \\
\hline (8) & R\&D intensity & 0.385 & 0.446 & 0.058 & 0.055 & 0.343 & 0.230 & 0.384 & 1 & & & & & \\
\hline (9) & ADV intensity & 0.128 & 0.180 & 0.095 & 0.108 & 0.093 & 0.062 & -0.169 & 0.326 & 1 & & & & \\
\hline (10) & HHI & 0.123 & 0.080 & 0.150 & 0.124 & 0.096 & 0.128 & 0.254 & 0.306 & -0.074 & 1 & & & \\
\hline (11) & IMPPEN & 0.459 & 0.480 & 0.337 & 0.375 & 0.068 & -0.015 & 0.290 & 0.039 & 0.093 & -0.001 & 1 & & \\
\hline (12) & EXPINT & 0.347 & 0.351 & 0.018 & 0.057 & 0.076 & -0.046 & 0.579 & 0.368 & -0.157 & 0.239 & 0.464 & 1 & \\
\hline (13) & KL ratio & -0.149 & -0.231 & 0.124 & -0.052 & 0.003 & 0.545 & -0.227 & -0.222 & -0.221 & 0.199 & -0.078 & -0.240 & 1 \\
\hline
\end{tabular}




\section{Appendix Table 3: Regression results (TFP dispersion)}

\begin{tabular}{|c|c|c|c|c|c|c|c|}
\hline & \multicolumn{4}{|c|}{ Productivity dispersion regressions } & \multirow{2}{*}{\multicolumn{3}{|c|}{$\begin{array}{c}\text { Central tendency regressions } \\
\text { Median lnTFP } \\
\end{array}$}} \\
\hline & \multicolumn{2}{|c|}{ Inter-quartile range (IQlnTFP) } & \multicolumn{2}{|c|}{ 10th-90th percentiles (IDlnTFP) } & & & \\
\hline & $(1)$ & $(2)$ & (3) & (4) & (5) & & $(6)$ \\
\hline R\&D intensity & $\begin{array}{r}-0.4833 \\
(-1.26)\end{array}$ & & $\begin{array}{r}-0.2879 \\
(-0.62)\end{array}$ & & $\begin{aligned} 1.5937 \\
(2.09)\end{aligned}$ & & \\
\hline IT ratio & & $\begin{array}{r}-0.0010 \\
(0.00)\end{array}$ & & $\begin{array}{r}0.1124 \\
(0.39)\end{array}$ & & & $\begin{array}{l}4.67166^{* * *} \\
(12.48)\end{array}$ \\
\hline ADV intensity & $\begin{array}{r}2.2881 \\
(1.64)\end{array}$ & $\begin{array}{r}2.2106 \\
(1.58)\end{array}$ & $\begin{array}{l}3.8190 * * \\
(2.24)\end{array}$ & $\begin{array}{l}3.7493 * * \\
(2.20)\end{array}$ & $\begin{array}{r}5.4457 \\
(1.95)\end{array}$ & $*$ & $\begin{array}{l}4.7300 * * \\
(2.13)\end{array}$ \\
\hline HHI & $\begin{array}{c}0.2277 * \\
(1.72)\end{array}$ & $\begin{array}{r}0.1398 \\
(1.22)\end{array}$ & $\begin{array}{r}0.1677 \\
(1.04)\end{array}$ & $\begin{array}{r}0.1246 \\
(0.89)\end{array}$ & $\begin{array}{r}-0.7031 \\
-2.66\end{array}$ & $* * *$ & $\begin{array}{r}-0.0336 \\
-0.19\end{array}$ \\
\hline IMPPEN & $\begin{array}{l}0.8520 * * * \\
(8.56)\end{array}$ & $\begin{array}{l}0.8709 * * * \\
(8.81)\end{array}$ & $\begin{array}{l}0.9584 * * * \\
(7.90)\end{array}$ & $\begin{array}{l}0.9725 * * * \\
(8.09)\end{array}$ & $\begin{array}{r}0.7717 \\
(3.89)\end{array}$ & $* * *$ & $\begin{array}{l}0.8260 \\
(5.28)\end{array}$ \\
\hline EXPINT & $\begin{array}{r}0.0767 \\
(0.85)\end{array}$ & $\begin{array}{r}0.0944 \\
(1.05)\end{array}$ & $\begin{array}{r}0.0566 \\
(0.51)\end{array}$ & $\begin{array}{r}0.0715 \\
(0.65)\end{array}$ & $\begin{array}{r}-0.6033 \\
(-3.35)\end{array}$ & $* * *$ & $\begin{array}{l}-0.48044^{* * *} \\
(-3.38)\end{array}$ \\
\hline No. of observations & 300 & 300 & 300 & 300 & 300 & & 300 \\
\hline R squared & 0.4559 & 0.4525 & 0.4652 & 0.4647 & 0.2831 & & 0.5468 \\
\hline F value & $15.32 * * *$ & $15.11 * * *$ & $15.91 * * *$ & $15.87 * * *$ & 7.22 & $* * *$ & $22.06 * * *$ \\
\hline
\end{tabular}

Notes: All equations include industry dummies and year dummies. $t$-values are in parentheses. $* * *, * *$, and $*$ indicate significance at the 1\%, 5\%, and $10 \%$ level, respectively.

\section{Appendix Table 4: Regression results (TFP dispersion): Excluding computer equipment industry}

\begin{tabular}{|c|c|c|c|c|c|c|}
\hline & \multicolumn{4}{|c|}{ Productivity dispersion regressions } & \multirow{2}{*}{\multicolumn{2}{|c|}{$\begin{array}{c}\text { Central tendency regressions } \\
\text { Median lnTFP }\end{array}$}} \\
\hline & \multicolumn{2}{|c|}{ Inter-quartile range (IQlnTFP) } & \multicolumn{2}{|c|}{ 10th-90th percentiles (IDlnTFP) } & & \\
\hline & (1) & (2) & (3) & (4) & (5) & (6) \\
\hline R\&D intensity & $\begin{array}{r}0.0924 \\
(0.57)\end{array}$ & & $\begin{array}{r}0.4089 \\
(1.64)\end{array}$ & & $\begin{array}{l}2.04488^{* * *} \\
(2.83)\end{array}$ & \\
\hline IT ratio & & $\begin{array}{r}0.1235 \\
(1.26)\end{array}$ & & $\begin{array}{c}0.2832 \\
(1.87)\end{array}$ & & $\begin{array}{l}4.7544 * * * \\
(14.43)\end{array}$ \\
\hline ADV intensity & $1.2163 * *$ & $1.2060 * *$ & $\begin{array}{l}2.53722^{* * *} \\
(2.82)\end{array}$ & $\begin{array}{l}2.5465 * * \\
(2.84)\end{array}$ & $\begin{array}{l}4.8516 * \\
(1.86)\end{array}$ & $\begin{array}{l}4.1987 * * \\
(2.15)\end{array}$ \\
\hline HHI & $\begin{array}{r}0.0259 \\
(0.46)\end{array}$ & $\begin{array}{r}0.0526 \\
(1.11)\end{array}$ & $\begin{array}{r}-0.0789 \\
(-0.92)\end{array}$ & $\begin{array}{r}0.0191 \\
(0.26)\end{array}$ & $\begin{array}{c}-0.8386 * * * \\
(-3.35)\end{array}$ & $\begin{array}{r}-0.0888 \\
(-0.55)\end{array}$ \\
\hline IMPPEN & $\begin{array}{r}0.0575 \\
(1.13)\end{array}$ & $\begin{array}{r}0.0568 \\
(1.13)\end{array}$ & $\begin{array}{r}0.0417 \\
(0.53)\end{array}$ & $\begin{array}{r}0.0361 \\
(0.46)\end{array}$ & $\begin{array}{r}0.1904 \\
(0.84)\end{array}$ & $\begin{array}{r}0.1966 \\
(1.16)\end{array}$ \\
\hline EXPINT & $\begin{array}{r}0.0076 \\
(0.20)\end{array}$ & $\begin{array}{r}0.0093 \\
(0.24)\end{array}$ & $\begin{array}{r}0.0010 \\
(0.02)\end{array}$ & $\begin{array}{r}-0.0029 \\
(-0.05)\end{array}$ & $\begin{array}{c}-0.6381 * * * \\
(-3.70)\end{array}$ & $\begin{array}{r}-0.5146 \\
(-4.01)\end{array}$ \\
\hline No. of observations & 290 & 290 & 290 & 290 & 290 & 290 \\
\hline R squared & 0.3397 & 0.343 & 0.4432 & 0.4449 & 0.3041 & 0.6101 \\
\hline F value & $9.08 * * *$ & $9.21 * * *$ & $14.04 * * *$ & $14.14 * * *$ & $7.71 * * *$ & $27.6 * * *$ \\
\hline
\end{tabular}

Notes: All equations include industry dummies and year dummies. $t$-values are in parentheses. $* * *, * *$, and $*$ indicate significance at the $1 \%, 5 \%$, and $10 \%$ level, respectively. 
Appendix Table 5: Regression results (TFP dispersion): Model controlling for survival rate

\begin{tabular}{|c|c|c|c|c|c|c|c|}
\hline & \multicolumn{4}{|c|}{ Productivity dispersion regressions } & \multirow{2}{*}{\multicolumn{3}{|c|}{$\begin{array}{c}\text { Central tendency regressions } \\
\text { Median lnTFP }\end{array}$}} \\
\hline & \multicolumn{2}{|c|}{ Inter-quartile range (IQlnTFP) } & \multicolumn{2}{|c|}{ 10th-90th percentiles (IDlnTFP) } & & & \\
\hline & $(1)$ & $(2)$ & (3) & $(4)$ & $(5)$ & & $(6)$ \\
\hline R\&D intensity & $\begin{array}{r}-0.4263 \\
(-1.24)\end{array}$ & & $\begin{array}{r}-0.3635 \\
(-0.84)\end{array}$ & & $\begin{array}{r}1.7605 \\
(2.45)\end{array}$ & $* * *$ & \\
\hline IT ratio & & $\begin{array}{r}-0.0912 \\
(-0.41)\end{array}$ & & $\begin{array}{r}0.0072 \\
(0.03)\end{array}$ & & & $\begin{array}{l}4.69677^{* * *} \\
(13.79)\end{array}$ \\
\hline ADV intensity & $\begin{array}{r}1.3388 \\
(1.04)\end{array}$ & $\begin{array}{r}1.3243 \\
(1.02)\end{array}$ & $\begin{array}{l}3.3169 * * \\
(2.04)\end{array}$ & $\begin{array}{l}3.3041 \\
(2.03)\end{array}$ & $\begin{array}{r}3.5617 \\
(1.33)\end{array}$ & & $\begin{array}{c}3.6004 \\
(1.80)\end{array}$ \\
\hline HHI & $\begin{array}{c}0.2339 * \\
(1.85)\end{array}$ & $\begin{array}{r}0.1397 \\
(1.30)\end{array}$ & $\begin{array}{r}0.2354 \\
(1.48)\end{array}$ & $\begin{array}{r}0.1620 \\
(1.20)\end{array}$ & $\begin{array}{r}-0.6898 \\
(-2.62)\end{array}$ & $* * *$ & $\begin{array}{r}0.0474 \\
(0.28)\end{array}$ \\
\hline IMPPEN & $\begin{array}{l}0.5834 * * * \\
(6.09)\end{array}$ & $\begin{array}{l}0.6032 * * * \\
(6.37)\end{array}$ & $\begin{array}{l}0.6393 * * * \\
(5.31)\end{array}$ & $\begin{array}{l}0.6564 * * * \\
(5.52)\end{array}$ & $\begin{array}{r}0.5419 \\
(2.72)\end{array}$ & $* * *$ & $\begin{array}{l}0.4717 \\
(3.21)\end{array}$ \\
\hline EXPINT & $\begin{array}{r}0.0689 \\
(0.79)\end{array}$ & $\begin{array}{r}0.0784 \\
(0.90)\end{array}$ & $\begin{array}{r}0.1152 \\
(1.05)\end{array}$ & $\begin{array}{r}0.1261 \\
(1.15)\end{array}$ & $\begin{array}{r}-0.6118 \\
(-3.36)\end{array}$ & $* * *$ & $\begin{array}{l}-0.5077 * * * \\
(-3.74)\end{array}$ \\
\hline SURVRT & $\begin{array}{r}0.0905 \\
(1.43)\end{array}$ & $\begin{array}{r}0.0865 \\
(1.37)\end{array}$ & $\begin{array}{l}0.1604 * * \\
(2.02)\end{array}$ & $\begin{array}{c}0.1546 * \\
(1.94)\end{array}$ & $\begin{array}{r}-0.0045 \\
-0.03\end{array}$ & & $\begin{array}{r}-0.1060 \\
-1.08\end{array}$ \\
\hline No. of observations & 270 & 270 & 270 & 270 & 270 & & 270 \\
\hline R squared & 0.3772 & 0.3735 & 0.4184 & 0.4166 & 0.273 & & 0.5945 \\
\hline F value & $9.78 * * *$ & $9.62 * * *$ & $11.61 * * *$ & $11.53 * * *$ & 6.06 & $* * *$ & $22.06 * * *$ \\
\hline
\end{tabular}

Notes: All equations include industry dummies and year dummies. t-values are in parentheses. $* * *, * *$, and $*$ indicate significance at the $1 \%, 5 \%$, and $10 \%$ level, respectively.

\section{Appendix Table 6: Regression results (TFP dispersion): Excluding computer equipment industry, Model controlling for survival rate}

\begin{tabular}{|c|c|c|c|c|c|c|}
\hline & \multicolumn{4}{|c|}{ Productivity dispersion regressions } & \multirow{2}{*}{\multicolumn{2}{|c|}{$\begin{array}{c}\text { Central tendency regressions } \\
\text { Median lnTFP }\end{array}$}} \\
\hline & \multicolumn{2}{|c|}{ Inter-quartile range (IQlnTFP) } & \multicolumn{2}{|c|}{ 10th-90th percentiles (IDlnTFP) } & & \\
\hline & $(1)$ & (2) & (3) & (4) & (5) & (6) \\
\hline R\&D intensity & $\begin{array}{r}0.0469 \\
(0.28)\end{array}$ & & $\begin{array}{r}0.2313 \\
(0.90)\end{array}$ & & $\begin{array}{l}2.0521 * * * \\
(2.93)\end{array}$ & \\
\hline IT ratio & & $\begin{array}{c}0.1752 * \\
(1.65)\end{array}$ & & $\begin{array}{l}0.3553 * * \\
(2.20)\end{array}$ & & $\begin{array}{l}4.8515 * * * \\
(15.71)\end{array}$ \\
\hline ADV intensity & $\begin{array}{c}1.0420 * \\
(1.67)\end{array}$ & $\begin{array}{c}1.0414 * \\
(1.68)\end{array}$ & $\begin{array}{l}2.9059 * * * \\
(3.05)\end{array}$ & $\begin{array}{l}2.9093 * * * \\
(3.08)\end{array}$ & $\begin{array}{r}3.5605 \\
(1.38)\end{array}$ & $\begin{array}{c}3.5688 * \\
(1.98)\end{array}$ \\
\hline HHI & $\begin{array}{r}0.0502 \\
(0.81)\end{array}$ & $\begin{array}{r}0.0728 \\
(1.42)\end{array}$ & $\begin{array}{r}0.0020 \\
(0.02)\end{array}$ & $\begin{array}{r}0.0761 \\
(0.97)\end{array}$ & $\begin{array}{l}-0.7729 * * * \\
(-3.00)\end{array}$ & $\begin{array}{r}0.0096 \\
(0.06)\end{array}$ \\
\hline IMPPEN & $\begin{array}{r}0.0179 \\
(0.32)\end{array}$ & $\begin{array}{r}0.0109 \\
(0.20)\end{array}$ & $\begin{array}{r}-0.0284 \\
(-0.34)\end{array}$ & $\begin{array}{r}-0.0467 \\
(-0.56)\end{array}$ & $\begin{array}{r}0.2441 \\
(1.06)\end{array}$ & $\begin{array}{r}0.0285 \\
(0.18)\end{array}$ \\
\hline EXPINT & $\begin{array}{r}0.0223 \\
(0.51)\end{array}$ & $\begin{array}{r}0.0276 \\
(0.64)\end{array}$ & $\begin{array}{r}0.0903 \\
(1.35)\end{array}$ & $\begin{array}{r}0.0965 \\
(1.47)\end{array}$ & $\begin{array}{l}-0.5938 * * * \\
(-3.29)\end{array}$ & $\begin{array}{c}-0.4718 * * * \\
(-3.75)\end{array}$ \\
\hline SURVRT1 & $\begin{array}{r}0.0511 \\
(1.64)\end{array}$ & $\begin{array}{r}0.0468 \\
(1.51)\end{array}$ & $\begin{array}{l}0.1085 * * \\
(2.27)\end{array}$ & $\begin{array}{l}0.1017 * * \\
(2.14)\end{array}$ & $\begin{array}{r}0.0394 \\
(0.30)\end{array}$ & $\begin{array}{r}-0.0695 \\
-0.77\end{array}$ \\
\hline No. of observations & 261 & 261 & 261 & 261 & 261 & 261 \\
\hline R squared & 0.3362 & 0.3442 & 0.4446 & 0.4546 & 0.2923 & 0.6551 \\
\hline F value & $7.89 * * *$ & $8.17 * * *$ & $12.47 * * *$ & $12.98 * * *$ & $6.43 * * *$ & $29.57 * * *$ \\
\hline
\end{tabular}

Notes: All equations include industry dummies and year dummies. $t$-values are in parentheses. $* * *, * *$, and $*$ indicate significance at the $1 \%, 5 \%$, and $10 \%$ level, respectively. 